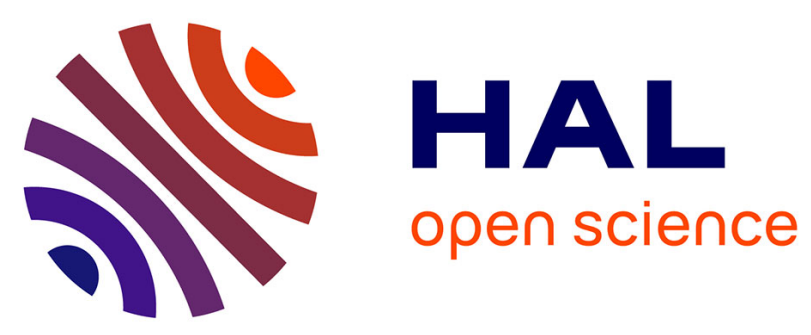

\title{
Spatiotemporal changes in surface sediment characteristics and benthic macrofauna composition off the Rhône River in relation to its hydrological regime
}

Paulo Bonifácio, Solveig Bourgeois, Céline Labrune, Jean-Michel Amouroux, Karine Escoubeyrou, Roselyne Buscail, Alicia Romero-Ramirez, François Lantoine, Gilles Vétion, Sabrina Bichon, et al.

\section{To cite this version:}

Paulo Bonifácio, Solveig Bourgeois, Céline Labrune, Jean-Michel Amouroux, Karine Escoubeyrou, et al.. Spatiotemporal changes in surface sediment characteristics and benthic macrofauna composition off the Rhône River in relation to its hydrological regime. Estuarine, Coastal and Shelf Science, 2014, 151, pp.196 - 209. 10.1016/j.ecss.2014.10.011 . hal-01090538

\section{HAL Id: hal-01090538 \\ https://hal.science/hal-01090538}

Submitted on 3 Dec 2014

HAL is a multi-disciplinary open access archive for the deposit and dissemination of scientific research documents, whether they are published or not. The documents may come from teaching and research institutions in France or abroad, or from public or private research centers.
L'archive ouverte pluridisciplinaire HAL, est destinée au dépôt et à la diffusion de documents scientifiques de niveau recherche, publiés ou non, émanant des établissements d'enseignement et de recherche français ou étrangers, des laboratoires publics ou privés. 
Spatiotemporal changes in surface sediment characteristics and benthic macrofauna composition off the Rhône River in relation with its hydrological regime

Paulo Bonifácio ${ }^{a, b}$, Solveig Bourgeois ${ }^{b}$, Céline Labrune ${ }^{b}$, Jean Michel Amouroux ${ }^{b}$, Karine Escoubeyrou ${ }^{c}$, Roselyne Buscail ${ }^{d}$, Alicia Romero-Ramirez ${ }^{a}$, François Lantoine ${ }^{b}$, Gilles Vétion ${ }^{b}$, Sabrina Bichon ${ }^{a}$, Martin Desmalades ${ }^{e}$, Béatrice Rivière ${ }^{b}$, Bruno Deflandre ${ }^{a}$, Antoine Grémare ${ }^{a}$

a Université de Bordeaux, CNRS, EPOC, UMR 5805, F-33400 Talence, France

b Sorbonne Universités, UPMC Université Paris 06, CNRS, LECOB, UMR 8222, Observatoire Océanologique, F-66650 Banyuls-sur-Mer, France

c Sorbonne Universités, UPMC Université Paris 06, CNRS, UMS 2348, Observatoire Océanologique, F-66650 Banyuls-sur-Mer, France

d Université Perpignan Via Domitia, CNRS, Centre de Formation et de Recherche sur les Environnements Méditerranéens, UMR 5110, F-66860 Perpignan, France

e Université de Perpignan, CNRS - EPHE, CRIOBE, USR 3278, F-66860 Perpignan cedex, France

Corresponding author: P. Bonifácio, bonif@me.com (phone number: +33556

22 3924) 


\section{Abstract}

The consequences of changes in the water flow of the Rhône River on surface sediment characteristics and benthic macrofauna composition were assessed within 3 distinct areas: (1) the delta front, (2) the prodelta, and (3) the distal zone. Five stations were sampled during or closely after: (1) an oceanic flood (April 2007), (2) a generalized flood (May 2008), (3) a Cevenol flood (December 2008), and (4) a dry period (July 2011). Measurements of sediment characteristics included granulometry $\left(D_{0.5}\right)$, bulk descriptors of sedimentary organics (OC, TN and THAA), descriptors of labile components of sedimentary organics (chloropigments, EHAA), and both descriptors of origin (Chl-b/Chl-a, C/N) and lability (Chl-a/(Chl-a+Phaeo-a), EHAA/THAA) of sedimentary organics. Sediment Profile Images were collected during April 2007, May 2008 and July 2011. Temporal changes in both sedimentary organics and benthic macrofauna were more important in the delta front and the prodelta than in the distal zone. Bulk characteristics of sedimentary organics presented decreasing inshore/offshore gradients during both April 2007 and July 2011 but not during May and December 2008. There were significant temporal changes in EHAA/THAA at all stations. Changes in benthic macrofauna composition differed between: (1) the delta front and the prodelta, and (2) the distal zone. In the former area, the dry period was associated with the establishment of a mature community characterized by high abundances and species richness. The best description of spatiotemporal changes in benthic macrofauna composition by surface sediment characteristics was obtained using $\mathrm{D}_{0.5}$, Chl-b/Chl-a, Chl-a/(Chl-a+Phaeoa) and EHAA, which supports the role of the quality of sedimentary organics in controlling benthic macrofauna composition. 
Keywords: Mediterranean Sea, Rhône River, Floods, Temporal variations, Particulate organic matter, Zoobenthos 


\section{Introduction}

River-dominated Ocean Margins (RiOMar) are land-ocean margin systems that are impacted by major rivers water, nutrient and particle discharges (McKee et al., 2004). As such they include large marine areas. RiOMar provide essential ecosystem services, such as habitat for many plant and animal species, nutrient recycling and fisheries (Levin et al., 2001) and are sensitive to a large diversity of natural and anthropogenic disturbances. On continental margins, in front of each river as well as lagoon mouths appears a preferential area of sediment accumulation under the wave storm base (Aloïsi and Monaco, 1975). These deposition areas, commonly named prodeltas, are the subaquaeous extension of aerial deltas in the inner-shelf around $30 \mathrm{~m}$ water depth (Bourrin and Durrieu de Madron, 2006). River prodeltas (i.e., the underwater parts of river deltas) are hydrodynamic environments experimenting high nutrient and terrestrial organic matter inputs, which enhance primary production (Cruzado and Velasquez, 1990; Lochet and Leveau, 1990). Their benthic compartments are affected by several co-occurring sedimentary (e.g. sedimentation/resuspension) and biogeochemical (e.g. bioturbation/mineralization) processes (Aller, 1998; Lansard et al., 2009; Pastor et al., 2011a; Pastor et al., 2011b). Together with shelf sediments, deltaic sediments are the most important area for organic carbon burial (Hedges and Keil, 1995) and for the decomposition of both terrestrial and marine particulate organic matter (POM) (Aller, 1998).

Deltaic sedimented POM is usually composed of: (1) continental (e.g. vascular land plants debris and soil-derived POM exported by rivers), and (2) marine material (e.g. marine autochthonous primary production and advective inputs) (Hedges et al., 1988; Goni et al., 1998; Leithold and Hope, 1999; Gordon and Goni, 2003). The 
balance between both sources clearly shifts from the dominance of continental to marine inputs along inshore/offshore gradients (Vonk et al., 2010). River floods affect temporal changes in this balance. They are important in controlling both the quantity and the quality of continental POM exported to the sea. These 2 parameters vary seasonally depending on water flows (Pont, 1997) and are also affected by drainage basin compositions. Dry seasons are usually associated with strong contributions of marine production, conversely to wet seasons, which are typically associated with strong contributions of soil-derived POM and plant debris carried by strong flows ( $\mathrm{Yu}$ et al., 2002). Although many studies have been devoted to the assessment of the relationships between spatiotemporal changes in deltaic sedimentary organics and hydrological regimes (Leithold and Hope, 1999; Bianchi et al., 2002; Yu et al., 2002), no real consensus has been reached yet regarding: (1) the quality (i.e., lability) of continental inputs (Leeuw and Largeau, 1993; Wakeham and Canuel, 2006; Mayer et al., 2008; Vonk et al., 2010), and (2) the effects of different types of floods on spatiotemporal changes in sedimentary organics within RiOMar.

The long-term impact of riverine inputs (e.g. sediments, organic matter) in controlling benthic macrofauna composition is well recognized as well. This paradigm was initially established based on the studies of major rivers such as the Amazon (Aller and Aller, 1986; Aller and Stupakoff, 1996) and the Changjiang (Rhoads et al., 1985; Aller and Aller, 1986). It has then been verified for smaller rivers (Occhipinti-Ambrogi et al., 2005; Wheatcroft, 2006; Akoumianaki and Nicolaidou, 2007; Harmelin-Vivien et al., 2009; Akoumianaki et al., 2013). According to the conceptual model proposed by Rhoads et al. (1985) spatial changes in benthic macrofauna composition off (major) rivers result from 2 opposite effects, namely: (1) 
a reduction of benthic macrofauna at the immediate vicinity of the river mouth due to the inputs of large quantities of sediments resulting in high sedimentation rates and instability, and (2) an increase of benthic macrofauna further offshore resulting from moderate organic enrichment. Conversely, there is no consensus about the occurrence of short-term effects of river inputs on benthic macrofauna, which were reported by Occhipinti-Ambrogi et al. (2005) and by Akoumianaki et al. (2013) but not by Wheatcroft (2006). Part of this discrepancy may result from differences between studies in the relative locations of monitored stations relative to inshore/offshore gradients. There is therefore a clear need for new studies combining appropriate spatial and temporal sampling to better describe the effects of changes in riverine inputs on benthic macrofauna composition.

The Rhône River (Figure 1) is the major source of freshwater and terrigenous particles to the Gulf of Lions (Aloisi et al., 1977). Its drainage Basin shows a strong geological heterogeneity and is subjected to highly fluctuating climatic conditions (Pont, 1997; Pont et al., 2002). Mean annual water and particle flows are $1700 \mathrm{~m}^{3} . \mathrm{s}^{-1}$ and $740010^{3}$ t.y $\mathrm{y}^{-1}$ (Pont et al., 2002). Temporal changes in water (up to $11000 \mathrm{~m}^{3} . \mathrm{s}^{-}$ ${ }^{1}$ ) and particle flows (up to $2270010^{3}$ t.y $^{-1}$ in years with strong floods) are very high, which is a characteristic of Mediterranean Rivers (Pont et al., 2002; Antonelli et al., 2008). Rhône River floods may be classified (Pont, 1997) as: (1) oceanic when resulting from precipitations in the Northern Basin and characterized by water flows rising slowly and regularly, (2) Cevenol when resulting from intense precipitations in the South-Western Basin and characterized by sudden and violent increase in water flows, (3) extensive Mediterranean when resulting from precipitations affecting the whole Southern Basin and mostly often associated with autumnal western 
perturbations, and (4) generalized when corresponding to a combination of the 3 first types. These events strongly differ in terms of both the quantity (Pont, 1997) and the origin (Eyrolle et al., 2012) of the particles transferred to the sea. The Rhône River prodelta is characterized by high sedimentation rates $\left(0.40-0.65 \mathrm{~cm} . \mathrm{y}^{-1}\right.$ as assessed through ${ }^{210} \mathrm{~Pb}$ measurements), which then decrease offshore $\left(0.20 \mathrm{~cm} \cdot \mathrm{y}^{-1}\right)$ (Zuo et al., 1997; Radakovitch et al., 1999; Miralles et al., 2005). It constitutes a transitional depositional area for terrigenous particles, associated organic matter and contaminants (Roussiez et al., 2005), which are later transferred to the deep sea through a succession of resuspension events mostly caused by storms (Ulses et al., 2008). Overall, strong temporal changes in its hydrological regime together with the heterogeneity of its drainage basin and classical spatial gradients within the deltaic area make the Rhône River an excellent model for the assessment of the effect of a major Mediterranean river on sedimentary organics and benthic macrofauna characteristics.

Spatiotemporal changes in surface sediment characteristics off the Rhône River have already been assessed in several studies (Alliot et al., 2003; Tesi et al., 2007; Lansard et al., 2009; Cathalot et al., 2010; Bourgeois et al., 2011; Pastor et al., 2011b; Cathalot et al., 2013). Part of these studies (Lansard et al., 2009; Cathalot et al., 2010) have mostly dealt with the assessment of sediment organic matter remineralization and thus have only considered a limited set of bulk biochemical descriptors. Others have included a wider set of biochemical parameters but have been restricted to an assessment of spatial changes (Alliot et al., 2003; Bourgeois et al., 2011; Pastor et al., 2011a; Pastor et al., 2011b; Cathalot et al., 2013). To our knowledge, the study by Tesi et al. (2007) is the only one, which combined the study 
of 2 contrasted situations in terms of Rhône River flows with the sampling of a large number of stations and the assessment of a reasonably large set of sedimentary organics biochemical characteristics. However, it still did not include classical organic matter quality descriptors such as EHAA/THAA and Chl-a/(Chl-a+Phaeo-a).

Several studies have assessed spatiotemporal changes in benthic macrofauna composition off the Rhône River as well (Salen-Picard et al., 2003; Hermand et al., 2008; Harmelin-Vivien et al., 2009; Labrune et al., 2012). A few of them have dealt with: (1) the whole benthic macrofauna but were restricted to a single sampling date (Hermand et al., 2008; Harmelin-Vivien et al., 2009; Labrune et al., 2012). They have shown the occurrence of strong longitudinal gradients in benthic macrofauna composition, which limits their use to ca 10 stations sampled only once in assessing the impact of Rhône River water flow (Hermand et al., 2008; Harmelin-Vivien et al., 2009). Another study was conversely restricted to the assessment of polychaete fauna at a single $70 \mathrm{~m}$ deep station but focussed on the assessment of the relationship linking Rhône River water flows and fauna compositions based on repeated seasonal sampling (Salen-Picard et al., 2003). It has suggested the dependency of benthic macrofauna composition on temporal changes in the Rhône River water flow with the distinction between 2 groups of species: one responding rapidly (i.e., around 3 months) and mostly composed of opportunistic species adapted to organically rich environments, and a second one responding with a 1-2 year time lag and mostly composed of (more) stable species. The question of the extrapolation of these results to other areas off the Rhône River mouth however still remains fully open due to the occurrence of strong spatial gradients and of their possible interactions with temporal changes in Rhône River water flow. 
In this context, the aim of this work was to further assess the effect of changes in Rhône River water flows on both: (1) the quantitative and qualitative characteristics of surface sediment, (2) benthic macrofauna composition, and (3) the possible control of the latter by the former.

\section{Materials and Methods}

\subsection{Study area}

The Rhône River hydrological basin covers an area of $97800 \mathrm{~km}^{2}$ (Figure 1) with a mean daily flow between 602 and $11000 \mathrm{~m}^{3} \cdot \mathrm{s}^{-1}$ (Pont et al., 2002; Antonelli et al., 2008). Low flows are usually recorded during summer whereas high flows occur during winter and spring (Pont, 1997). The mean daily concentration of suspended particulate matter (SPM) is $180 \mathrm{mgDW}^{-1} \mathrm{I}^{-1}$. It can decrease to $26 \mathrm{mgDW} . \mathrm{I}^{-1}$ during dry periods (Pont et al., 2002). The Rhône River accounts for about $80 \%$ of total particulate matter riverine inputs to the Gulf of Lions (Aloisi et al., 1977; Durrieu de Madron et al., 2000). There are 3 distinct sedimentary units in front of its mouth (Aloisi, 1986): (1) the delta front between 5 and $30 \mathrm{~m}$ depth, (2) the prodelta between 30 and $60 \mathrm{~m}$ depth, and (3) the distal zone between 60 and $100 \mathrm{~m}$. 


\subsection{Rhône River flows}

Rhône River water flow $\left(\mathrm{m}^{3} \cdot \mathrm{s}^{-1}\right)$ and SPM $\left(\mathrm{mgDW} . \mathrm{I}^{-1}\right)$ were measured in Arles, (47.5 $\mathrm{km}$ upstream of the river mouth, data provided by MOOSE: Mediterranean Ocean Observing System on Environment - http://www.moose-network.fr).

\subsection{Sampling}

The 5 sampled stations were located between 2 and $13 \mathrm{~km}$ off the Rhône River mouth along a gradient corresponding to the preferential direction of the river plume (Figure 1, Table 1). Station A was in the delta front; station B in the prodelta and stations N, C and D in the distal zone. Sampling took place in April 2007, May and December 2008 and July 2011 for: (1) sediments characteristics and (2) benthic macrofauna. Sediment Profile Images (SPIs) were also collected in April 2007, May 2008 and July 2011.

\subsection{Sediment characteristics}

Sediment cores (9.5 cm internal diameter) were collected using an Oktopus ${ }^{\circledR}$ GmbH MUC 8/100 multicorer in April 2007, May 2008 and December 2008; and an Oktopus® GmbH MC 6 multicorer in July 2011. There were 3 cores per sampled station. The upper half centimetre of each core was sliced and homogenized. Each sample was then split in two subsamples (one for granulometry and pigment and one 
for biochemistry) and frozen at $-20^{\circ} \mathrm{C}$. The subsamples used for organic carbon, total nitrogen and amino acids were later freeze-dried.

\section{Granulometry}

Sediment granulometry was assessed using a Malvern Mastersizer® 2000 laser microgranulometer and expressed as median grain diameter $\left(D_{0.5}\right)$. There was no replicate at stations N, C and D in December 2008 and all stations in July 2011.

\section{Organic carbon and total nitrogen}

Organic carbon and total nitrogen concentrations (OC and TN, respectively) were measured on homogenized, precisely weighed samples with an automatic $\mathrm{CN}$ analyzer LECO 2000 , after acidification with $2 \mathrm{M} \mathrm{HCl}$ (overnight, at $50^{\circ} \mathrm{C}$ ) in order to remove carbonates prior to the analyses of organic carbon (Cauwet et al., 1990). Precision for $\mathrm{OC}$ and $\mathrm{TN}$ measurements are about $2 \%$. $\mathrm{C} / \mathrm{N}$ ratios were expressed as atomic ratios. There was no replicate for OC in May and December 2008 and for TN in May and December 2008 and July 2011.

\section{Chloropigments}

Triplicates (100 to $500 \mathrm{mgFW})$ samples were extracted overnight $\left(5^{\circ} \mathrm{C}\right.$ in darkness) in $5 \mathrm{ml}$ of $90 \%$ acetone (final concentration). Fluorescence measurements were then performed using a Perkin Elmer® LS55 spectrofluorometer according to (Neveux and Lantoine, 1993). This allowed for the quantification of chlorophyll-a (Chl-a), chlorophyll-b (Chl-b) and phaeophytin-a (Phaeo-a).

\section{Amino acids}


Total hydrolysable amino acids (THAA) and enzymatically hydrolysable amino acids (EHAA) were analysed on triplicates. THAA were extracted by acid hydrolysis. EHAA were extracted following the biomimetic approach proposed by Mayer et al. (1995). THAA and EHAA were analysed as isoindole derivatives following reaction with an orthophtaldialdehyde solution (Lindroth and Mopper, 1979). During July 2011, THAA and EHAA were quantified by fluorescence measurements (excitation wavelength of $340 \mathrm{~nm}$ and emission wavelength of $453 \mathrm{~nm}$ ) using a Perkin Elmer ${ }^{\circledR}$ LS55 fluorescence spectrometer. During April 2007, May 2008 and December 2008, fluorescent derivatives were separated by reverse-phase high-performance liquid chromatography (Gynkotek-Dionex system) on a C18 HPLC column using non-linear gradient of methanol-acetate buffer, and detected by fluorescence at $450 \mathrm{~nm}$ using an excitation wavelength of $335 \mathrm{~nm}$.

\subsection{Benthic macrofauna}

At each station, 5 samples of $0.1 \mathrm{~m}^{2}$ were collected using a van Veen grab, sieved on a $1 \mathrm{~mm}$ mesh and fixed (5\% buffered formalin). Macrofauna were then sorted, identified to the lowest tractable taxonomic group and counted.

\subsection{Sediment Profile Images}

SPIs were collected using two similar Ocean Imaging® systems. Ten deployments were carried out at each station, except in May 2008 (4 deployments at 
station $\mathrm{A}$ and 9 at station $\mathrm{N}$ due to bad weather conditions). SPIs were analyzed using the SpiArcBase software (Romero-Ramirez et al., 2013).

\subsection{Data analysis}

\section{$\underline{\text { Sediment characteristics }}$}

Non-Metric Multidimensional Scaling (nMDS) and hierarchical clustering (Euclidean distance, group average linking) were performed on normalized sediment characteristics $\left(\mathrm{D}_{0.5}, \mathrm{OC}, \mathrm{TN}, \mathrm{THAA}, \mathrm{EHAA}, \mathrm{Chl}-a, \mathrm{Chl}-b, \mathrm{Chl}-b / \mathrm{Chl}-a\right.$, Phaeo- $a, \mathrm{C} / \mathrm{N}$, EHAA/THAA and Chl-a/(Chl-a+Phaeo-a)). The significance of differences among the groups derived from hierarchical clustering was tested using SIMilarity PROFile (SIMPROF) procedure (Clarke et al., 2008).

\section{Benthic macrofauna}

Total abundance, species richness (SR) and Pielou's evenness (J') were used as bulk descriptors of benthic macrofauna compositions. SR is the number of species present in a sample whereas $\mathrm{J}$ ' indicates how homogeneous is the individual abundance of each species within a sample. $\mathrm{J}$ ' is between 0 and 1 . This last value indicates that all species are represented by the same number of individuals. Replicated samples were pooled and abundance-based compositions were also compared through nMDS and hierarchical clustering (square-root transformed data, Bray-Curtis similarity, group average linking). SIMPROF tests (were used together 
with ANOSIM for the cluster composed by stations $N, C$ and $D$ ) to assess the significance of internal structures in identified clusters (Clarke et al., 2008). SIMilarity PERcentages analyses (Clarke, 1993) were performed to identify the species contributing most to between-clusters dissimilarity.

$\underline{\text { Relationships linking sediment characteristics and benthic macrofauna }}$ compositions

A BIO-ENV procedure (Clarke and Ainsworth, 1993) was performed to identify the subset of sediment characteristics, which best described spatiotemporal changes in benthic macrofauna composition. The set of tested sediment characteristics included $\mathrm{D}_{0.5}$, Chl-a, Chl-b/Chl-a, Phaeo-a, Chl-a/(Chl-a+Phaeo-a), EHAA, THAA, EHAA/THAA, OC and $\mathrm{C} / \mathrm{N}$. The correlations of each retained environmental variable with benthic macrofauna compositions were assessed using Mantel tests.

All procedures were completed using the PRIMER 6® software package.

\section{Results}

\subsection{Rhône River flows}

Strong temporal changes in daily water and particle flows were observed between 2007 and 2011 (Figure 2). The May 2008 cruise took place during a flood. The April 2007 and December 2008 cruises took place 42 and 26 days after a flood. 
Conversely, the July 2011 cruise took place after an extended (i.e., 191 day long) period of low water flows.

\subsection{Sediment characteristics}

Overall, sediments grains tended to be coarser and more variable in size among dates at station A (between 6.7 in May and $69.2 \mu \mathrm{m}$ in December 2008; Table 2, Figure $3 A$ ). $D_{0.5}$ at station B was between 12.9 in July and $23.9 \mu \mathrm{m}$ in May 2008. Surface sediments tended to be finer and less variable at stations N, C and D.

Temporal changes in OC, TN and THAA were the lowest at stations $\mathrm{N}, \mathrm{C}$ and D. They were the highest at station A for OC (Figure 3B) and TN, and at station B for THAA (Table 2). All 3 descriptors showed decreasing values offshore during April 2007 and July 2011. Conversely, May and December 2008 were characterized by low values of OC, TN and THAA at station A and maximal ones at station $B$. This pattern was especially marked for THAA.

Overall, EHAA showed the same pattern for the 3 bulk descriptors of sedimentary organics with: (1) high temporal changes at station A, (2) decreasing inshore/offshore gradients during April 2007 and July 2011, and (3) low concentrations at station A and the highest concentrations at station B during May and December 2008 (Table 2, Figure 3C). Temporal changes in EHAA at station B were however low. Temporal changes in Chl-a (Figure 3D) and Chl-b were high at station $A$, intermediate at station $B$ and low at stations $N, C$ and D (Table 2). Decreasing inshore/offshore gradients were marked during April 2007 and July 2011. 
Concentrations at stations A and B were much higher during April 2007 than July 2011. Chl-a and Chl-b concentrations were maximal at station B during May and December 2008. This pattern was especially marked for Chl-b during December 2008.

Temporal changes in $\mathrm{C} / \mathrm{N}$ were highest at station $\mathrm{A}$ (Table 2). It was especially high at station A in December 2008 and tended to be highest at this particular date than during the 3 other cruises at all other 4 stations. Temporal changes in Chl$\mathrm{b} / \mathrm{Chl}-\mathrm{a}$ were the highest at station $\mathrm{A}$, intermediate at station $\mathrm{B}$, and low at stations $\mathrm{N}$, C and D (Table 2). During April 2007, May 2008 and December 2008, there were clear inshore/offshore gradients with the highest values at stations $A$ and $B$ during December 2008. During July 2011, the highest Chl-b/Chl-a was recorded at station B.

Temporal changes in EHAA/THAA were slightly higher at station $\mathrm{A}$ than at the 4 other stations (Table 2, Figure 3E). EHAA/THAA always tended to be similar at all stations with the exception of station A during July 2011. EHAA/THAA also tended to be higher during July 2011 at all stations. Temporal changes in Chl-a/(Chl-a+Phaeoa) were higher at station $A$ than at the 4 other stations (Table 2, Figure 3F). There were always strong decreasing inshore/offshore gradients.

The nMDS (Figure 4A) confirmed that the temporal variability of surface sediment characteristics was higher at station A, intermediate at station B and lower at stations N, C and D. Station A during May 2008, and station B during July 2011, showed the characteristics of sedimentary organics the closest to those of stations $\mathrm{N}, \mathrm{C}$ and D. The hierarchical clustering (Figure 4B) confirmed this pattern with the 
identification of 4 significantly differing clusters: (I) station A in April 2007 and July 2011, and station B in April 2007, May and December 2008, (II) stations N, C and D in April 2007 and May 2008, (III) stations N and C in December 2008, and (IV) stations C and D in July 2011. Station A in May and December 2008, station D in December 2008 and stations B and N in July 2011 were not included in these main clusters.

\subsection{Benthic macrofauna}

4558 specimens belonging to 142 taxa were identified. Benthic macrofauna was mainly composed of polychaetes ( $80 \%$ of total overall abundance) followed by crustaceans and molluscs (7\% each) and minor groups, including echinoderms, sipunculans, echiurans, cnidarians, hemichordates, nemerteans, platyhelminthes and phoronideans (for a total of $6 \%$ ). Sternaspis scutata (Polychaeta) accounted for $36 \%$ of total abundance, whereas all others species accounted for less than $5 \%$ each. S. scutata (Polychaeta) was the top rank species at all stations except station A in April 2007 (Thyasira flexuosa, Mollusca), May 2008 (Heteromastus filiformis, Polychaeta) and December 2008 (Polycirrus sp., Polychaeta); station B during December 2008 (Lumbrineris latreilli, Polychaeta); and station N in May 2008 (Poecilochaetus serpens, Polychaeta). Four taxa (S. scutata, H. filiformis, Nephtys kersivalensis (all Polychaeta) and nemerteans) were always present at station A versus $13,12,11$ and 13 taxa at stations $B, N, C$ and $D$, respectively.

Temporal changes in abundances were higher at stations $A$ and $B$, intermediate at station $\mathrm{N}$ lower at stations $\mathrm{C}$ and $\mathrm{D}$ (Table 2, Figure 5A). Abundances 
at station A were between 144 and 1522 ind.m ${ }^{-2}$ during April 2007 and July 2011. Abundances at station B were between 310 and 1700 ind. $\mathrm{m}^{-2}$ during May 2008 and July 2011. Temporal patterns were similar at these 2 stations except for higher abundances at station B during April 2007. Abundances at station N were between 238 and 622 ind. $\mathrm{m}^{-2}$ during May 2008 and December 2008. They were intermediate during April 2007 (358 ind. $\mathrm{m}^{-2}$ ) and July 2011 (426 ind. $\mathrm{m}^{-2}$ ). Abundances at station C and D were higher during April 2007 (436 and 294 ind. $\mathrm{m}^{-2}$, respectively) and July 2011 (442 and 284 ind. $\mathrm{m}^{-2}$, respectively)) and lower during May (258 and 202 ind. $\mathrm{m}^{-2}$ for stations C and D) and December 2008 (246 and 210 ind. $\mathrm{m}^{-2}$ for stations C and D).

Temporal changes in SR were the highest at station A (Table 2, Figure 5B). Both the lowest (15 taxa.0.5 $\mathrm{m}^{-2}$ during May 2008) and the highest SR (57 taxa.0.5m 2 in July 2011) were recorded at this station. High SR were as well recorded at station B during April 2007 (39 taxa.0.5 $\mathrm{m}^{-2}$ ), station N during December 2008 (37 taxa. $0.5 \mathrm{~m}^{-2}$ ) and station C during May 2008 (36 taxa.0.5 $\mathrm{m}^{-2}$ ). The only clear inshore/offshore gradient was recorded during July 2011 with SR ranging from 57 to 39 taxa. $0.5 \mathrm{~m}^{-2}$ at stations $A$ and $D$, respectively.

J' were between 0.55 (station C in April 2007) and 0.91 (station N in May 2008). They did not show any clear temporal or spatial patterns (Table 2, Figure $5 \mathrm{C}$ ). At stations $A$ and $B$, the lowest values were recorded during July 2011 , when both total abundances and SR were the highest.

The nMDS (Figure 6A) showed that temporal changes in macrofauna composition were highest at station $A$, intermediate at station B and lowest at 
stations N, C and D. The hierarchical clustering (Figure 6B) confirmed this pattern with the identification of 4 clusters: (I) station A in April 2007, May and December 2008, (II) stations A and B in July 2011, (III) station B in April 2007, May and December 2008, and (IV) stations N, C and D during all cruises. There was no internal structure within this last cluster (SIMPROF tests, $p>0.05$ ). Conversely, the ANOSIM test $(\rho=0.87, p=0.001)$ showed significant temporal changes at stations $N$, C and D.

Average dissimilarity between groups I and II was $76.6 \%$ with Sternaspis scutata (12.3\%, Polychaeta), Laonice cirrata (5.2\%, Polychaeta), Lumbrineris latreilli (4.6\%, Polychaeta) and Thyasira flexuosa (4.2\%, Mollusca) contributing most. Average dissimilarity between groups I and III was $70.7 \%$ with Labidoplax digitata (5.2\%, Echinodermata), S. scutata (5.2\%, Polychaeta), L. latreilli (5.1\%, Polychaeta), Nephtys hystricis (4.62\%, Polychaeta) and Goniada maculata (4.3\%, Polychaeta) contributing most. Average dissimilarity between groups II and III was $54.3 \%$ with $S$. scutata (11.1\%, Polychaeta), L. cirrata (6.5\%, Polychaeta) and T. flexuosa (5.0\%, Mollusca) contributing most. Average dissimilarity between subgroups IVa and IVb was $47.5 \%$ with S. scutata (7.7\%, Polychaeta), Athanas nitescens (3.9\%, Crustacea), Harpinia dellavallei (3.3\%, Crustacea), Chaetozone spp. $(3.1 \%$, Polychaeta) and Abra nitida (3.0\%, Mollusca) contributing most. Average dissimilarity between subgroups IVa and IVc was $50.9 \%$ with S. scutata $(4.5 \%$, Polychaeta), Ampharete grubei (4.3\%, Polychaeta), L. cirrata (3.4\%, Polychaeta) and L. latreilli (3.0\%, Polychaeta) contributing most. Average dissimilarity between subgroups IVb and IVc was 49.4\% with $A$. grubei (5.0\%, Polychaeta), L. cirrata (4.4\%, Polychaeta) and S. scutata (3.8\%, Polychaeta) contributing most. 


\subsection{SPIs}

Temporal changes in SPIs characteristics (Figure 7) were the strongest at station A with: (1) a very thin apparent Redox Potential Discontinuity (aRPD) layer and almost no biogenic structures in April 2007, (2) a thick flood layer with a few large biogenic structures in May 2008, and (3) an average thickness of the aRPD of $38 \mathrm{~mm}$ with numerous biogenic structures including tubes in July 2011. The flood layer observed in May 2008 was thickest at station A and then tended to decrease offshore (data not shown). The aRPD at stations B, N, C and D tended to be thicker in May 2008 than in April 2007 and in July 2011.

\subsection{Relationship between sediment characteristics and benthic macrofauna compositions}

The best correlation $(\rho=0.795, p=0.01)$ between the similarity matrices of benthic macrofauna composition and sediment characteristics was found using $D_{0.5}$, Chl-b/Chl-a, Chl-a/(Chl-a+Phaeo-a) and EHAA. Each of these variables correlated positively with benthic macrofauna composition (Mantel tests, $\mathrm{p}=0.001$ in all cases). 


\section{Discussion}

4.1 Sampling in relation with the hydrological regime of the Rhône River

The distinction between the 4 types of floods of the Rhône River is often based on SPM, with oceanic floods associated with the lowest concentrations (i.e., $<500$ mgDW.I ${ }^{-1}$ ) (Pont, 1997). It can also rely on the activities of ${ }^{238} \mathrm{U},{ }^{232} \mathrm{Th},{ }^{137} \mathrm{Cs}$ and ${ }^{(239+240)} \mathrm{Pu}$ (Eyrolle et al., 2012). This last approach has been used to classify Rhône River floods between 2000 and 2012 (Zebracki et al., 2015). The March 2007, May 2008 and November 2008 floods were respectively classified as: oceanic, generalized and Cevenol. Sampling was thus associated with 3 different types of floods. Floods can also be of different intensities (Pont (1997); Figure 2A). In the last 20 years, several studies have reported water flows and suspended particulate discharges for different time periods: 1992-1995, 2003 and 2006-2008 (Pont, 2002; Antonelli et al., 2008; Eyrolle et al., 2012). Maximal water flow was reported by Antonelli et al (2008) in December 2003 with an extreme flow of $11000 \mathrm{~m}^{3} . \mathrm{s}^{-1}$ for a total particulate discharge of $540010^{3}$ t.flood ${ }^{-1}$. Maximal suspended particulate discharge was of $1262410^{3}$ t.flood $^{-1}$ in the 1992-1995 time period. The May 2008 flood, with a water flow of $4156 \mathrm{~m}^{3} . \mathrm{s}^{-1}$ and a particulate discharge of $467010^{3}$ t.flood 1 (Eyrolle et al., 2012), can thus be considered as reasonably strong regarding particle flows. Conversely, the March 2007 and the November 2008 floods (3269 $\mathrm{m}^{3} \cdot \mathrm{s}^{-1}$ and $4806 \mathrm{~m}^{3} \cdot \mathrm{s}^{-1}$, respectively) can be considered as of low and intermediate intensity based on water flows. Another source of heterogeneity is the time lag between the last floods and samplings. These were 42 and 26 days in April 2007 and December 2008, whereas the May 2008 cruise took place during the flood. The July 2011 cruise took place after an extended (i.e., 191 day long) period of low water 
flows. Sampling thus proved representative of a large variety of hydrological regimes and therefore allows for the assessment of the responses of both surface sediment characteristics and benthic macrofauna composition, provided that the temporal dynamics of such responses are properly taken into account.

\subsection{Sedimentary organics}

\section{Quantitative changes}

Previous studies have shown the occurrence of decreasing inshore/offshore gradient in sediment grain size (Cathalot et al., 2010; Bourgeois et al., 2011; Pastor et al., 2011b) and sedimentary organics concentrations (Alliot et al., 2003; Hermand et al., 2008; Lansard et al., 2009; Cathalot et al., 2010; Bourgeois et al., 2011). The resulting positive correlation between sediment grain size and sedimentary organics concentrations contradicts the general negative correlation linking these 2 parameters (Mayer, 1994). This mostly results from the fact that the Rhône River constitutes the major source of organic inputs in the studied area (Pastor et al., 2011b). During the present study, decreasing inshore/offshore gradients in both sediment grain size and sedimentary organic contents were observed during April 2007 and July 2011. Spatial distributions differed during May and December 2008 with: (1) much finer and much coarser sediments in the delta front, respectively; and (2) higher sedimentary organics concentrations in the prodelta than in the delta front at both dates. Differences in sediment grain size in the delta front can be related with: (1) the type of the last flood, and (2) the time lag between this flood and sampling. The occurrence of finer sediment in May 2008 probably results from the 
fact that the May 2008 generalized flood mostly affected the Durance River, which required the opening of the Serre-Ponçon dam. This resulted in the liberation of large amounts of fine particles, which later sedimented in the delta front as indicated by the flood layer observed on $29^{\text {th }}$ May 2008 (Figure 7). Such a pattern was not observed at station B, which was sampled on $28^{\text {th }}$ May 2008 (i.e., just at the beginning of the flood). However, Cathalot et al. (2010) later observed a $30 \mathrm{~cm}$ thick flood layer with low OC on $6^{\text {th }}$ June 2008 near this station. Moreover, based on the analysis of ${ }^{7} \mathrm{Be}$ and ${ }^{210} \mathrm{~Pb}_{\mathrm{xs}}$ activities on SPM collected in Arles, Eyrolle et al. (2012) suggested that SPM during the May 2008 flood mostly originated from the reworking of old degraded soils initially trapped in the Serre-Ponçon dam, which is known to trap organically poor fine clay particles originating from intense erosion acting on a soil lacking vegetation (Pont et al., 2002). Overall, the occurrence of finer surface sediment grain size in the delta front than in the prodelta during May 2008 largely results from the fact that station $B$ was sampled before being affected by the deposition of the flood layer. Accordingly, the occurrence of lower sedimentary organic contents in the delta front probably results from the fact that the $\mathrm{OC}$ of the sediment constitutive of the flood layer was low (Cathalot et al., 2010).

The occurrence of sandy sediments in the delta front in December 2008 probably results from 2 distinct processes. First, the November 2008 flood classified as Cevenol. Such events are sudden and result in high water and particle flows. Antonelli et al. (2008) found a positive correlation between SPM grain size in Arles and particle flow. Since, sandy particles settle quicker than fine particles, this may account for the occurrence of higher concentrations of sand following the flood. Another possible cause of the discrepancies in sediment grain size within the delta 
front between May and December 2008 is linked to the fact that station A was sampled during the flood in May and 26 days after the flood in December. Prodeltaic systems of the Gulf of Lions are areas of transitory deposits for continental inputs, which are later resuspended and transferred offshore (Buscail et al., 1995; Durrieu de Madron et al., 2000; Ulses et al., 2008). For instance, 2 kilometres off the Rhône River mouth, Marion et al. (2010) observed the erosion of a $5 \mathrm{~cm}$ deposits within 20 days after the November 2006 flood. Resuspension preferentially affects fines and mostly occurs during autumn and winter (Ulses et al., 2008). It may thus have contributed to clear surface sediments at station $A$ of their finest components between their deposition (i.e., during the November 2008 flood) and December 2008 sampling. The occurrence of higher sedimentary organic concentrations in the prodelta during December 2008 may result from the granulometry effect (Mayer, 1994).

\section{Qualitative changes}

$\mathrm{C} / \mathrm{N}$ and $\mathrm{Chl}-b / \mathrm{Chl}-a$ ratios classically show decreasing inshore/offshore gradients off the Rhône River mouth (Lansard et al., 2009; Cathalot et al., 2010; Bourgeois et al., 2011). For both descriptors, results from the present study show no strong temporal changes except in December 2008 in the delta front and to a lesser extent in the prodelta where high Chl-b/Chl-a supported the contribution of continental plant detritus to sedimentary organics (Jeffrey, 1976; Meyers, 1994; Hedges et al., 1997; Tesi et al., 2007; Cathalot et al., 2013). This may be related to the November 2008 Cevenol flood since these events mostly originate from the 
Cevennes area, which is densely forested. Besides changes in continental inputs, higher Chl-b/Chl-a close to the Rhône River mouth may also result from subsequent physical sorting (Tesi et al., 2007), which tends to export fine particles with lower contents of vascular plant detritus offshore (Goni et al., 1998; Leithold and Hope, 1999). This pattern is supported by spatiotemporal changes in $\mathrm{C} / \mathrm{N}$. The $\mathrm{C} / \mathrm{N}$ of soil organic matter is typically between 7 and 15 (Baldock et al., 1992). Values recorded during April 2007, May 2008 and July 2011 were in the upper range (11-15) with no clear inshore/offshore gradient. Values recorded in December 2008 were higher with a clear decreasing inshore/offshore gradient, which is coherent with a higher contribution of continental vascular plant material $(C / N>20$; Baldock et al. (1992)) to sedimentary organics, and/or a reduction of this contribution due to dilution or preferential degradation during the transport offshore (Baldock et al., 1992). The first of these 2 hypotheses is probably the most valid because $\mathrm{C} / \mathrm{N}$ ratios did not decrease offshore during the 3 other cruises and EHAA/THAA never decreased offshore.

Spatiotemporal changes in Chl-a/(Chl-a+Phaeo-a) and EHAA/THAA ratios clearly differed. Chl-a/(Chl-a+Phaeo-a) ratios always decreased offshore with, except to some extent in the delta front, no marked temporal change. Conversely, EHAA/THAA ratios showed no offshore gradient during either cruise but did show temporal changes with high values in July 2011, intermediate values in April 2007 and low values in May and December 2008. In the delta front Chl-a/(Chl-a+Phaeo-a) ratios correlated negatively with $\mathrm{Chl}-b / \mathrm{Chl}-a$ ratios, which is coherent with the lower lability classically attributed to continental than to marine plant material (Wakeham et al., 1997). The decreasing trend and the lack of temporal changes at higher depth 
result from the fact that: (1) Rhône River inputs are the major source of plant material to the sediment/water interface of all stations, and (2) irrespective of slight differences in the original freshness of bulk plant materials, its most labile components are quickly degraded during their transfer offshore. EHAA/THAA ratios are indicative of a different, much larger and overall less labile component of sedimentary organics (Wakeham et al., 1997). The lack of offshore gradient probably results from the fact that the degradation taking place during the offshore transfer affects a minor fraction of the nitrogenous fraction of sedimentary organics. Conversely, the occurrence of significant temporal changes in EHAA/THAA may reflect differences in the lability of the nitrogenous component of sedimentary organics depending on seasons or hydrologic conditions of the Rhône River. Results from the present study suggest that such changes are mainly related with changes in the intensity of continental inputs with higher values during April 2007 (intermediate particle flow, oceanic flood) and July 2011 (low particle flow, dry period) and lower ones during May and December 2008 (high particle flows, generalized and Cevenol floods).

\subsection{Benthic macrofauna}

Although still significant in the distal zone (according to the results of the ANOSIM test at least), temporal changes in macrofauna composition were clearly much more marked in the delta front and to a lesser extent in the prodelta, which is similar to what was observed for surface sediment characteristics. 
In the Rhône River delta front, sedimentation rates can reach up to $0.65 \mathrm{~cm} . \mathrm{y}^{-}$ ${ }^{1}$ (Zuo et al., 1997; Miralles et al., 2005) which, according to the model proposed by Rhoads et al. (1985), can account for minimal SR and abundance of benthic macrofauna in the delta front during April 2007, May and December 2008. The fact that benthic macrofauna SR (April 2007, May and December 2008) and abundances (April 2007) tended to be higher in the prodelta, which is located further offshore supports this model. Conversely, benthic macrofauna abundances in the delta front and the prodelta were close in May and December 2008 (i.e., following the generalized and Cevenol floods, respectively), which may be indicative of the extension of the negatively affected area during major floods and therefore also tends to support the Rhoads et al. (1985) model.

The nMDS and the analysis of benthic macrofauna characteristics at stations A and B show that July 2011 clearly differed from the 3 other sampling dates with: (1) much higher abundances and SR, and (2) higher abundances of Sternaspis scutata (Polychaeta), Laonice cirrata (Polychaeta), Lumbrineris latreilli (Polychaeta, station A only) and Thyasira flexuosa (Mollusca). The extended period of reduced water flows before July 2011 clearly enhanced the establishment of a more mature benthic macrofauna community in the delta front and the prodelta. This community included both tube-dwelling and deep-burrowing macrofauna as indicated by sediment profile imagery in the prodelta (Figure 7). More generally, July 2011 corresponded to the inshore enlargement of the spatial distributions of several species including Abra nitida (Mollusca), Abyssoninoe hibernica (Polychaeta), Alpheus glaber (Crustacea), Ampharete grubei (Polychaeta), Apseudes spp. (Crustacea), Chaetozone spp. (Polychaeta), Goniada maculata (Polychaeta), L. 
cirrata (Polychaeta), Malmgrenia lilianae (Polychaeta), T. flexuosa (Mollusca) and Thysanocardia procera (Sipunculida), which were found up to the delta front. Such a positive effect of low flow on benthic macrofauna abundance and SR has already been reported for several major rivers (Aller and Stupakoff, 1996; Occhipinti-Ambrogi et al., 2005). This supports previous observations (on an annual basis and without any time lag in the response of benthic polychaete fauna to changes in Rhône River flow) by Harmelin-Vivien et al. (2009) and is also in good agreement with the Rhoads et al. (1985) model.

SPI data suggest an almost immediate impact of the May 2008 flood in the delta front with the onset of the deposition of a flood layer only 1 day after the beginning of the flood event (Figure 7). Together with subsequent observations by Cathalot et al. (2010) (see above) they suggest an almost immediate effect of the hydrological regime of the Rhône River on the composition of benthic macrofauna within its delta front and prodelta. Moreover, the analysis of temporal changes in benthic macrofauna compositions in the delta front and the prodelta shows that May 2008 (during a generalized flood) was intermediate between December 2008 (26 days after a Cevenol flood) and April 2007 (42 days after an oceanic flood). This underlines the importance of the type of floods relative to the time lag between last flood and sampling in affecting benthic macrofauna composition within the delta front.

Spatiotemporal changes in benthic macrofauna composition were much more reduced in the distal zone. Salen-Picard et al. (2003) reported a high interannual variability at a $70 \mathrm{~m}$ deep station which was attributed to interannual changes in the hydrological regime of the Rhône River. The results of the ANOSIM test support the 
existence of such variability, even though the overall weakness of differences in benthic macrofauna composition associated with 4 contrasted hydrological conditions clearly complicates the assessment of a causal relationship between water flows and benthic fauna compositions. The analysis of between-cruises similarities in benthic macrofauna compositions at stations in the distal zone shows that July 2011 was closest to December 2008 and farthest from April 2007, which differs from what was observed in the delta front and prodelta (see above). The balance between the 2 opposite effects constitutive of the Rhoads et al. (1985) model thus clearly differs in the delta front and in the distal zone. In the former, negative effects are most pronounced due to high sedimentation (Zuo et al., 1997; Miralles et al., 2005) and direct inputs of POM are occasionally so high that they negatively affect benthic macrofauna (Pearson and Rosenberg, 1978; Labrune et al., 2012). Conversely, disturbances resulting from sedimentation and direct POM inputs are much smaller in the distal zone, which tend to switch the overall balance of the effects of floods towards positive values. Such discrepancies between the delta front and the prodelta, and the distal zone probably account for differences in the nature and the intensity of the response of benthic macrofauna composition to changes in the hydrological regime of the Rhône River. They are as well likely to account for differences in the time lag associated with these responses since the negative effect of sedimentation is almost immediate (Wheatcroft, 2006), whereas, for some feeding types at least, the response to changes in POM availability is much longer (SalenPicard et al., 2003). 
4.4 Relationship between sediment characteristics and benthic macrofauna

Sediments characteristics, in general, and organic matter availability, in particular, are known to largely control both the spatial and temporal patterns of benthic macrofauna composition (Pearson and Rosenberg, 1978; Grémare et al., 2002; Labrune et al., 2012). The other way around, benthic macrofauna may also alter both the physical and biogeochemical properties of marine sediments through nutrition and/or bioturbation (Meysman et al., 2006; Bernard et al., 2012). Both of these interactions may contribute to the correlation between sediment characteristics and benthic macrofauna composition. Based on the sampling of 16 stations during April 2007, Labrune et al. (2012) reported that spatial changes in benthic macrofauna composition off the Rhône River mouth correlated with the OC contents of surface sediments. Pastor et al. (2011b) reported a similar correlation between $\mathrm{OC}$ and benthic oxygen consumption, with no significant effect of the quality/lability of sedimentary organics, which they attributed to the strong dominance of the organic matter source constituted by the inputs from the Rhône River. Results from the present study show that spatiotemporal changes in benthic macrofauna composition are best described when combining 4 factors including $\mathrm{D}_{0.5}$, EHAA, Chl$a /($ Chl- $a+$ Phaeo- $a)$ and Chl-b/Chl-a. Besides sediment granulometry $\left(D_{0.5}\right)$, these include a quantitative descriptor of a labile component of sedimentary organics (EHAA) and a qualitative descriptor of sedimentary organics (Chl-a/(Chl-a+Phaeoa)). Results from the present study thus support the better correlation found between meiofauna abundance and quantitative descriptors of labile (i.e., EHAA and lipids) rather than bulk (i.e., OC, TN and THAA) components of sedimentary organics already found in the open Gulf of Lions (Grémare et al., 2002). Moreover, they 
suggest that temporal changes in the quality of sedimentary organics in relation with changes in the hydrological regime of the Rhône River contribute to control temporal changes in the composition of benthic macrofauna.

There are however several lines of evidences suggesting that these parameters are not the only ones accounting for differences between the compositions of benthic macrofauna during July 2011 and the 3 other dates. First, $\mathrm{OC}$ and EHAA contents in the delta front and the prodelta were almost equivalent during April 2007 and July 2011, whereas the characteristics and the compositions of benthic macrofauna conversely strongly differed between these 2 dates. Second, the co-variation between abundance, SR and J' did not match the classical Pearson and Rosenberg (1978) model since low evenness were associated with high abundances but also with high SR during July 2011. It is therefore likely that spatiotemporal changes in benthic macrofauna composition were also affected by other factors than the Rhône River water flow and resulting organic inputs. High abundances of small individuals of the dominant polychaete Sternaspis scutata (Polychaeta) during July 2011 may for instance result from a recent recruitment. This hypothesis is consistent with the reported preferential recruitment of this species during summertime in the Chinhae Bay (Lim and Hong, 1996). However, Hermand et al. (2008) reported the preferential recruitment of $S$. scutata (Polychaeta) during wintertime (i.e., December and January) off the Rhône River, which suggest that high abundances of S. scutata (Polychaeta) in the delta front and the prodelta in July 2011 are indeed associated with low water fluxes and do not result from an interaction with its lifecycle. This is further supported by the fact that low water flow periods are known to enhance the 
colonization of more inshore zones of the Amazon continental shelf by juveniles of benthic macrofauna (Aller and Stupakoff, 1996). 


\section{Acknowledgements}

We would like to thank C. Rabouille who coordinated the CHACCRA program. We thank the captains and crew members of the RV Tethys II and Côte de la Manche (CNRS-INSU) for technical assistance during sampling. Special thanks to L.

Rigouin, D. Cabanes, M. Richard for their technical assistance in laboratory during this work. In particular, the authors thank F. Charles for his help at sea and A. Pruski for her contribution to amino acids data. The authors acknowledge the AERMC and the SOERE-MOOSE sponsored by INSU and Alliance ALLENVI for supplying the data of the Rhône River (water and SPM flows). This work was partly funded by the French national ANR program CHACCRA (Contract no ANR-VULN-06-001-01), the French EC2CO-PNEC program RiOMar and the French EC2CO-PNEC and LEFECYBER program BIOMIN. It is part of the $\mathrm{PhD}$ Thesis of $\mathrm{P}$. Bonifácio who was funded by IFREMER (convention 09/3211321) and the Agence de l'Eau CorseMéditerranée (convention n²010 0871). S. Bourgeois was supported by a grant from the French Ministry of Research. 


\section{References}

Akoumianaki, I., Nicolaidou, A., 2007. Spatial variability and dynamics of macrobenthos in a Mediterranean delta front area: the role of physical processes. Journal of Sea Research 57, 47-64.

Akoumianaki, I., Papaspyrou, S., Kormas, K.A., Nicolaidou, A., 2013. Environmental variation and macrofauna response in a coastal area influenced by land runoff. Estuarine, Coastal and Shelf Science 132, 34-44.

Aller, J.Y., Aller, R.C., 1986. General characteristics of benthic faunas on the Amazon inner continental shelf with comparison to the shelf off the Changjiang River, East China Sea. Continental Shelf Research 6, 291-310.

Aller, J.Y., Stupakoff, I., 1996. The distribution and seasonal characteristics of benthic communities on the Amazon shelf as indicators of physical processes. Continental Shelf Research 16, 717-751.

Aller, R.C., 1998. Mobile deltaic and continental shelf muds as suboxic, fluidized bed reactors. Marine Chemistry 61, 143-155.

Alliot, E., Younes, W.A.N., Romano, J.C., Rebouillon, P., Massé, H., 2003. Biogeochemical impact of a dilution plume (Rhone River) on coastal sediments. Estuarine, Coastal and Shelf Science 57, 357-367.

Aloisi, J.C., 1986. Sur un modèle de sédimentation deltaïque: contribution à la connaissance des marges passives. Ph.D. Thesis, Université de Perpignan. 
Aloïsi, J.C., Monaco, A., 1975. La sédimentation infralittorale. Les prodeltas nordméditerranéens. Comptes Rendus de l'Académie des Sciences de Paris 280: 28332836.

Aloisi, J.C., Auffret, G.A., Auffret, J.P., Barusseau, J.P., Hommeril, P., Larsonneur, C., Monaco, A., 1977. Essai de modélisation de la sédimentation actuelle sur les plateaux continentaux français. Bulletin de la Société Géologique Française 7, 182195.

Antonelli, C., Eyrolle, F., Rolland, B., Provansal, M., Sabatier, F., 2008. Suspended sediment and ${ }^{137}$ Cs fluxes during the exceptional December 2003 flood in the Rhone River, southeast France. Geomorphology 95, 350-360.

Baldock, J.A., Oades, J.M., Waters, A.G., Peng, X., Vassallo, A.M., Wilson, M.A., 1992. Aspects of the chemical structure of soil organic materials as revealed by solid-state ${ }^{13} \mathrm{C}$ NMR spectroscopy. Biogeochemistry 16, 1-42.

Bernard, G., Grémare, A., Maire, O., Lecroart, P., Meysman, F.J.R., Ciutat, A., Deflandre, B., Duchêne, J.C., 2012. Experimental assessment of particle mixing fingerprints in the deposit-feeding bivalve Abra alba (Wood), Journal of Marine Research 70, 689-718.

Bianchi, T.S., Mitra, S., McKee, B.A., 2002. Sources of terrestrially-derived organic carbon in lower Mississippi River and Louisiana shelf sediments: implications for differential sedimentation and transport at the coastal margin. Marine Chemistry 77, 211-223. 
Bourgeois, S., Pruski, A.M., Sun, M.Y., Buscail, R., Lantoine, F., Kerhervé, P., Vétion, G., Rivière, B., Charles, F., 2011. Distribution and lability of land-derived organic matter in the surface sediments of the Rhône prodelta and the adjacent shelf (Mediterranean Sea, France): a multi proxy study. Biogeosciences 8, 3107-3125.

Bourrin, F., Durrieu de Madron, X., 2006. Contribution to the study of coastal rivers and associated prodeltas to sediment supply in Gulf of Lions (NW Mediterranean Sea). Vie et Milieu/Life and Environnement 56: 307-314.

Buscail, R., Pocklington, R., Germain, C., 1995. Seasonal variability of the organic matter in a sedimentary coastal environment: sources, degradation and accumulation (continental shelf of the Gulf of Lions - Northwestern Mediterranean Sea). Continental Shelf Research 15, 843-869.

Cathalot, C., Rabouille, C., Pastor, L., Deflandre, B., Viollier, E., Buscail, R., Grémare, A., Treignier, C., Pruski, A.M., 2010. Temporal variability of carbon recycling in coastal sediments influenced by rivers: assessing the impact of flood inputs in the Rhône River prodelta. Biogeosciences 7, 1187-1205.

Cathalot, C., Rabouille, C., Tisnérat-Laborde, N., Toussaint, F., Kerhervé, P., Buscail, R., Loftis, K., Sun, M.Y., Tronczynski, J., Azoury, S., Lansard, B., Treignier, C., Pastor, L., Tesi, T., 2013. The fate of river organic carbon in coastal areas: a study in the Rhône River delta using multiple isotopic $\left(\delta^{13} \mathrm{C}, \Delta^{14} \mathrm{C}\right)$ and organic tracers. Geochimica et Cosmochimica Acta 118, 33-55.

Cauwet, G., Gadel, F., Sierra, M.M.D., Donard, O., Ewald, M., 1990. Contribution of the Rhone River to Organic-Carbon Inputs to the Northwestern Mediterranean-Sea. Continental Shelf Research 10, 1025-1037. 
Clarke, K.R., 1993. Non-parametric multivariate analyses of changes in community structure. Australian Journal of Ecology 18, 117-143.

Clarke, K.R., Ainsworth, M., 1993. A method of linking multivariate community structure to environmental variables. Marine Ecology Progress Series 92, 205-219.

Clarke, K.R., Somerfield, P.J., Gorley, R.N., 2008. Testing of null hypotheses in exploratory community analyses: similarity profiles and biota-environment linkage. Journal of Experimental Marine Biology and Ecology 366, 56-69.

Cruzado, A., Velásquez, Z., 1990. Nutrients and phytoplankton in the Gulf of lions, northwestern mediterranean. Continental Shelf Research 10: 931-942.

Durrieu de Madron, X., Abassi, A., Heussner, S., Monaco, A., Aloisi, J.C., Radakovitch, O., Giresse, P., Buscail, R., Kerhervé, P., 2000. Particulate matter and organic carbon budgets for the Gulf of Lions (NW Mediterranean). Oceanologica Acta $23,717-730$.

Eyrolle, F., Radakovitch, O., Raimbault, P., Charmasson, S., Antonelli, C., Ferrand, E., Aubert, D., Raccasi, G., Jacquet, S., Gurriaran, R., 2012. Consequences of hydrological events on the delivery of suspended sediment and associated radionuclides from the Rhône River to the Mediterranean Sea. Journal of Soils and Sediments 12, 1479-1495.

Goni, M.A., Ruttenberg, K.C., Eglinton, T.I., 1998. A reassessment of the sources and importance of land-derived organic matter in surface sediments from the Gulf of Mexico. Geochimica et Cosmochimica Acta 62, 3055-3075. 
Gordon, E.S., Goni, M.A., 2003. Sources and distribution of terrigenous organic matter delivered by the Atchafalaya River to sediments in the northern Gulf of Mexico. Geochimica et Cosmochimica Acta 67, 2359-2375.

Grémare, A., Medernach, L., DeBovee, F., Amouroux, J.M., Vétion, G., Albert, P., 2002. Relationships between sedimentary organics and benthic meiofauna on the continental shelf and the upper slope of the Gulf of Lions (NW Mediterranean). Marine Ecology Progress Series 234, 85-94.

Harmelin-Vivien, M.L., Bănaru, D., Dierking, J., Hermand, R., Letourneur, Y., SalenPicard, C., 2009. Linking benthic biodiversity to the functioning of coastal ecosystems subjected to river runoff (NW Mediterranean). Animal Biodiversity and Conservation 32, 135-145.

Hedges, J.I., Clark, W.A., Cowie, G.L., 1988. Organic matter sources to the water column and surficial sediments of a marine bay. Limnology and Oceanography 33, 1116-1136.

Hedges, J.I., Keil, R.G., 1995. Sedimentary organic matter preservation: an assessment and speculative synthesis. Marine Chemistry 49, 81-115.

Hedges, J.I., Keil, R.G., Benner, R., 1997. What happens to terrestrial organic matter in the ocean? Organic Geochemistry 27, 195-212.

Hermand, R., Salen-Picard, C., Alliot, E., Degiovanni, C., 2008. Macrofaunal density, biomass and composition of estuarine sediments and their relationship to the river plume of the Rhone River (NW Mediterranean). Estuarine, Coastal and Shelf Science 79, 367-376. 
Jeffrey, S.W., 1976. A report of green algal pigments in the central North Pacific Ocean. Marine Biology 37, 33-37.

Labrune, C., Romero-Ramirez, A., Amouroux, J.M., Duchêne, J.C., Desmalades, M., Escoubeyrou, K., Buscail, R., Grémare, A., 2012. Comparison of ecological quality indices based on benthic macrofauna and sediment profile images: a case study along an organic enrichment gradient off the Rhône River. Ecological Indicators 12, 133-142.

Lansard, B., Rabouille, C., Denis, L., Grenz, C., 2009. Benthic remineralization at the land-ocean interface: a case study of the Rhône River (NW Mediterranean Sea). Estuarine, Coastal and Shelf Science 81, 544-554.

Leeuw, J.W., Largeau, C., 1993. A review of macromolecular organic compounds that comprise living organisms and their role in kerogen, coal, and petroleum formation. In: Engel, M.H., Macko, S.A. (Eds.), Organic Geochemistry. Springer US, pp. 23-72.

Leithold, E.L., Hope, R.S., 1999. Deposition and modification of a flood layer on the northern California shelf: lessons from and about the fate of terrestrial particulate organic carbon. Marine Geology 154, 183-195.

Levin, L.A., Boesch, D.F., Covich, A., Dahm, C., Erséus, C., Ewel, K.C., Kneib, R.T., Moldenke, A., Palmer, M.A., Snelgrove, P., Strayer, D., Weslawski, J.M., 2001. The function of marine critical transition zones and the importance of sediment biodiversity. Ecosystems 4, 430-451. 
Lim, H.S., Hong, J.S., 1996. Distribution and growth pattern of Sternaspis scutata (Polychaeta: Sternaspidae) in Chinhae Bay, Korea. Journal of the Korean Fisheries Society $29,537-545$.

Lindroth, P., Mopper, K., 1979. High performance liquid chromatographic determination of subpicomole amounts of amino acids by precolumn fluorescence derivatization with o-phthaldialdehyde. Analytical Chemistry 51, 1667-1674.

Lochet, F., Leveau, M., 1990. Transfers between a eutrophic ecosystem, the river Rhône, and an oligotrophic ecosystem, the north-western Mediterranean Sea. Hydrobiologia 207, 95-103.

Marion, C., Dufois, F., Arnaud, M., Vella, C., 2010. In situ record of sedimentary processes near the Rhône River mouth during winter events (Gulf of Lions, Mediterranean Sea). Continental Shelf Research 30, 1095-1107.

Mayer, L. 1994. Surface area control of organic carbon accumulation in continental shelf sediments. Geochimica et Cosmochimica Acta 58, 1271-1284.

Mayer, L.M., Schick, L.L., Allison, M.A., 2008. Input of nutritionally rich organic matter from the Mississippi River to the Louisiana coastal zone. Estuaries and Coasts 31, 1052-1062.

Mayer, L.M., Schick, L.L., Sawyer, T., Plante, C.J., Jumars, P.A., Self, R.L., 1995. Bioavailable amino acids in sediments: a biomimetic, kinetics-based approach. Limnology and Oceanography 40, 511-520.

McKee, B.A., Aller, R.C., Allison, M.A., Bianchi, T.S., Kineke, G.C., 2004. Transport and transformation of dissolved and particulate materials on continental margins 
influenced by major rivers: benthic boundary layer and seabed processes. Continental Shelf Research 24, 899-926.

Meyers, P.A., 1994. Preservation of elemental and isotopic source identification of sedimentary organic matter. Chemical Geology 114, 289-302.

Meysman, J.F.R., Middelburg, J.J., Heip, C.H.R., 2006. Bioturbation: a fresh look ar Darwin's las idea. Trends in Ecology \& Evolution 12-21, 688-695.

Miralles, J., Radakovitch, O., Aloisi, J.C., $2005 .{ }^{210} \mathrm{~Pb}$ sedimentation rates from the Northwestern Mediterranean margin. Marine Geology 216, 155-167.

Neveux, J., Lantoine, F., 1993. Spectrofluorometric assay of chlorophylls and phaeopigments using the least-square approximation technique. Deep Sea Research Part I: Oceanographic Research Papers 40, 1747-1765.

Occhipinti-Ambrogi, A., Savini, D., Forni, G., 2005. Macrobenthos community structural changes off Cesenatico coast (Emilia Romagna, Northern Adriatic), a sixyear monitoring programme. Science of The Total Environment 353, 317-328.

Pastor, L., Cathalot, C., Deflandre, B., Viollier, E., Soetaert, K., Meysman, F.J.R., Ulses, C., Metzger, E., Rabouille, C., 2011a. Modeling biogeochemical processes in sediments from the Rhône River prodelta area (NW Mediterranean Sea). Biogeosciences 8, 1351-1366.

Pastor, L., Deflandre, B., Viollier, E., Cathalot, C., Metzger, E., Rabouille, C., Escoubeyrou, K., Lloret, E., Pruski, A.M., Vétion, G., Desmalades, M., Buscail, R., Grémare, A., 2011b. Influence of the organic matter composition on benthic oxygen 
demand in the Rhône River prodelta (NW Mediterranean Sea). Continental Shelf Research 31, 1008-1019.

Pearson, T.H., Rosenberg, R., 1978. Macrobenthic sucession in relation to organic enrichment and pollution of the marine environment. Oceanography and Marine Biology: An Annual Review 16, 229-311.

Pont, D., 1997. Les débits solides du Rhône à proximité de son embouchure: données récentes (1994-1995). Revue de Géographie de Lyon 72, 23-33.

Pont, D., Simonnet, J.P., Walter, A.V., 2002. Medium-term changes in suspended sediment delivery to the ocean: consequences of catchment heterogeneity and river management (Rhône River, France). Estuarine, Coastal and Shelf Science 54, 1-18.

Radakovitch, O., Charmasson, S., Arnaud, M., Bouisset, P., $1999 .{ }^{210} \mathrm{~Pb}$ and caesium accumulation in the Rhône delta sediments. Estuarine, Coastal and Shelf Science 48, 77-92.

Rhoads, D.C., Boesch, D.F., Zhican, T., Fengshan, X., Liqiang, H., Nilsen, K.J., 1985. Macrobenthos and sedimentary facies on the Changjiang delta platform and adjacent continental shelf, East China Sea. Continental Shelf Research 4, 189-213.

Romero-Ramirez, A., Grémare, A., Desmalades, M., Duchêne, J.C., 2013. Semiautomatic analysis and interpretation of sediment profile images. Environmental Modelling and Software 47, 42-54.

Roussiez, V., Ludwig, W., Probst, J.L., Monaco, A., 2005. Background levels of heavy metals in surficial sediments of the Gulf of Lions (NW Mediterranean): an 
approach based on ${ }^{133} \mathrm{Cs}$ normalization and lead isotope measurements. Environmental Pollution 138, 167-177.

Salen-Picard, C., Arlhac, D., Alliot, E., 2003. Responses of a Mediterranean soft bottom community to short-term (1993-1996) hydrological changes in the Rhone river. Marine Environmental Research 55, 409-427.

Tesi, T., Miserocchi, S., Goni, M.A., Langone, L., 2007. Source, transport and fate of terrestrial organic carbon on the western Mediterranean Sea, Gulf of Lions, France. Marine Chemistry 105, 101-117.

Ulses, C., Estournel, C., Durrieu de Madron, X., Palanques, A., 2008. Suspended sediment transport in the Gulf of Lions (NW Mediterranean): impact of extreme storms and floods. Continental Shelf Research 28, 2048-2070.

Vonk, J.E., Sánchez-García, L., Semiletov, I., Dudarev, O., Eglinton, T., Andersson, A., Gustafsson, Ö., 2010. Molecular and radiocarbon constraints on sources and degradation of terrestrial organic carbon along the Kolyma paleoriver transect, East Siberian Sea. Biogeosciences 7, 3153-3166.

Wakeham, S.G., Canuel, E.A., 2006. Degradation and Preservation of Organic Matter in Marine Sediments. In: Volkman, J.K. (Ed.), Marine Organic Matter: Biomarkers, Isotopes and DNA, The Handbook of Environmental Chemistry. Springer-Verlag, Berlin/Heidelberg, pp. 295-321.

Wakeham, S.G., Lee, C., Hedges, J.I., Hernes, P.J., Peterson, M.J., 1997. Molecular indicators of diagenetic status in marine organic matter. Geochimica et Cosmochimica Acta 61, 5363-5369. 
Wheatcroft, R.A., 2006. Time-series measurements of macrobenthos abundance and sediment bioturbation intensity on a flood-dominated shelf. Progress in Oceanography 71, 88-122.

Yu, Z., Zhang, Q., Kraus, T., Dahlgren, R.A., Anastasio, C., Zasoski, R.J., 2002. Contribution of amino compounds to dissolved organic nitrogen in forest soils. Biogeochemistry 61, 173-198.

Zebracki, M., Eyrolle-Boyer, F., Evrard, O., Claval, D., Mourier, B., Gairoard, S., Cagnat, X., Antonelli, C., 2015. Tracing the origin of suspended sediment in a large Mediterranean river by combining continuous river monitoring and measurement of artificial and natural radionuclides. Sci. Total Environ. 502, 122-132.

Zuo, Z., Eisma, D., Gieles, R., Beks, J., 1997. Accumulation rates and sediment deposition in the northwestern Mediterranean. Deep-Sea Research Part II 44, 597609. 
1 Table 1 : Latitude, longitude (WGS84, degrees and decimal minutes), depth and 2 distance from the Rhône River mouth of the 5 sampled stations.

Station $\begin{array}{cccc}\text { Latitude } & \text { Longitude } \\ (\mathrm{N}) & (\mathrm{W}) & \begin{array}{c}\text { Depth } \\ (\mathrm{m})\end{array} & \begin{array}{c}\text { Distance from } \\ \text { the Rhône River } \\ \text { mouth }(\mathrm{km})\end{array}\end{array}$

$\begin{array}{cccc}\text { A } & 43^{\circ} 18.690^{\prime} 04^{\circ} 51.042^{\prime} & 24 & 1.9 \\ \text { B } & 43^{\circ} 18.013^{\prime} 04^{\circ} 50.068^{\prime} & 54 & 3.0 \\ \text { N } & 43^{\circ} 17.626^{\prime} 04^{\circ} 47.896^{\prime} & 67 & 5.5 \\ \text { C } & 43^{\circ} 16.343^{\prime} 04^{\circ} 46.565^{\prime} & 76 & 8.6 \\ \text { D } & 43^{\circ} 14.917^{\prime} 04^{\circ} 43.613^{\prime} & 74 & 13.0\end{array}$


Table 2: Mean values of surface sediment and benthic macrofauna characteristics. Sta: Stations, $\mathrm{D}_{0.5}$ : median grain size, OC: organic carbon, $\mathrm{TN}$ : total nitrogen, $\mathrm{C} / \mathrm{N}$ : ratio between organic carbon and total nitrogen, Chl-a: chlorophyll-a, Chl-b: chlorophyll- $b$, Chl-b/Chl-a: ratio between chlorophyll- $b$ and chlorophyll-a, Phaeo-a: phaeophytin-a, Chl-a/(Chl-a+Phaeo-a): ratio between chlorophyll-a and the sum of chlorophyll-a and phaeophytin-a, EHAA: enzymatically hydrolysable amino acid, THAA: total hydrolysable amino acid, EHAA/THAA: ratio between enzymatically and total hydrolysable amino acids, SR: species richness and J': Pielou's evenness. \pm standard deviation $(n=3)$.

\begin{tabular}{|c|c|c|c|c|c|c|c|c|c|c|c|c|c|c|c|c|c|}
\hline Cruise & Sta. & $\begin{array}{l}\text { Sampling } \\
\text { date }\end{array}$ & $\begin{array}{c}D_{0.5} \\
(0-0.5 \mathrm{~mm}) \\
(\mu \mathrm{m})\end{array}$ & $\begin{array}{l}\mathrm{OC} \\
(\% \mathrm{DW})\end{array}$ & $\begin{array}{l}\mathrm{TN} \\
(\% \mathrm{DW})\end{array}$ & $\begin{array}{c}\mathrm{C} / \mathrm{N} \\
\text { (atomic ratio) }\end{array}$ & $\begin{array}{c}\text { Chl-a } \\
\left(\mu \mathrm{g} \cdot \mathrm{g}^{-1} \mathrm{DW}\right)\end{array}$ & $\begin{array}{c}\text { Chl-b } \\
\left(\mu \mathrm{g} \cdot \mathrm{g}^{-1} \mathrm{DW}\right)\end{array}$ & $\begin{array}{c}\text { Chl-b/Chl-a } \\
(\%)\end{array}$ & $\begin{array}{c}\text { Phaeo-a } \\
\left(\mu \mathrm{g} . \mathrm{g}^{-1} \mathrm{DW}\right)\end{array}$ & $\begin{array}{c}\text { Chl-a/(Chl- } \\
a+\text { Phaeo-a) (\%) }\end{array}$ & $\begin{array}{c}\text { EHAA } \\
\left(\mathrm{mg}^{-1} \mathrm{~g} \mathrm{DW}\right)\end{array}$ & $\begin{array}{c}\text { THAA } \\
\left(\mathrm{mg} \cdot \mathrm{g}^{-1} \mathrm{DW}\right)\end{array}$ & $\begin{array}{c}\text { EHAA/THAA } \\
(\%)\end{array}$ & $\begin{array}{l}\text { Abundance } \\
\text { (ind. } m^{-2} \text { ) }\end{array}$ & $\begin{array}{c}\mathrm{SR} \\
\left(\operatorname{taxa} .0 .5 \mathrm{~m}^{-2}\right)\end{array}$ & $J^{\prime}$ \\
\hline \multirow[t]{5}{*}{$\begin{array}{l}\text { April } \\
2007\end{array}$} & A & 4/20/2007 & $37.40 \pm 3.05$ & $1.83 \pm 0.18$ & $0.17 \pm 0.004$ & $12.90 \pm 1.42$ & $9.78 \pm 0.82$ & $01.38 \pm 0.06$ & $14.20 \pm 0.82$ & $20.51 \pm 1.49$ & $32.26 \pm 0.52$ & $1.17 \pm 0.19$ & $3.77 \pm 0.30$ & $28.21 \pm 1.07$ & 144 & 20 & 0.88 \\
\hline & B & 4/20/2007 & $14.83 \pm 0.55$ & $1.53 \pm 0.08$ & $0.15 \pm 0.003$ & $12.10 \pm 0.45$ & $4.99 \pm 0.49$ & $0.51 \pm 0.06$ & $10.17 \pm 0.24$ & $21.76 \pm 1.24$ & $18.62 \pm 0.88$ & $0.86 \pm 0.05$ & $3.14 \pm 0.03$ & $27.49 \pm 1.76$ & 642 & 39 & 0.69 \\
\hline & $\mathrm{N}$ & 4/24/2007 & $14.01 \pm 2.42$ & $1.19 \pm 0.21$ & $0.10 \pm 0.002$ & $13.46 \pm 2.11$ & $2.57 \pm 0.60$ & $0.18 \pm 0.13$ & $6.29 \pm 4.33$ & $14.31 \pm 0.18$ & $15.13 \pm 2.95$ & $0.68 \pm 0.02$ & $2.82 \pm 0.35$ & $24.52 \pm 2.67$ & 358 & 26 & 0.68 \\
\hline & C & 4/23/2007 & $11.38 \pm 1.12$ & $1.20 \pm 0.05$ & $0.11 \pm 0.003$ & $12.78 \pm 0.63$ & $1.64 \pm 0.12$ & $0.06 \pm 0.05$ & $3.79 \pm 3.63$ & $12.19 \pm 1.19$ & $11.90 \pm 0.48$ & $0.69 \pm 0.03$ & $2.38 \pm 0.07$ & $28.91 \pm 1.99$ & 436 & 34 & 0.55 \\
\hline & D & 4/23/2007 & $10.45 \pm 0.22$ & $1.02 \pm 0.03$ & $0.11 \pm 0.001$ & $11.23 \pm 0.38$ & $1.56 \pm 0.29$ & 0.00 & 0.00 & $13.76 \pm 2.83$ & $10.21 \pm 0.43$ & $0.72 \pm 0.04$ & $2.54 \pm 0.09$ & $28.17 \pm 1.85$ & 294 & 34 & 0.68 \\
\hline \multirow[t]{5}{*}{$\begin{array}{l}\text { May } \\
2008\end{array}$} & A & $5 / 29 / 2008$ & $6.74 \pm 0.63$ & 1.13 & 0.09 & 14.81 & $3.07 \pm 0.43$ & $0.29 \pm 0.07$ & $9.47 \pm 2.84$ & $4.58 \pm 0.57$ & $40.16 \pm 0.77$ & $0.43 \pm 0.04$ & $2.18 \pm 0.13$ & $19.68 \pm 0.80$ & 178 & 15 & 0.73 \\
\hline & B & 5/28/2008 & $23.87 \pm 6.67$ & 1.75 & 0.17 & 12.3 & $3.80 \pm 0.63$ & $0.31 \pm 0.09$ & $8.02 \pm 1.65$ & $17.70 \pm 1.11$ & $17.60 \pm 1.52$ & $0.93 \pm 0.12$ & $5.62 \pm 0.63$ & $16.57 \pm 1.47$ & 310 & 28 & 0.82 \\
\hline & $\mathrm{N}$ & $5 / 30 / 2008$ & $10.65 \pm 1.90$ & 1.00 & 0.10 & 12.03 & $1.62 \pm 0.59$ & $0.07 \pm 0.06$ & $3.48 \pm 3.41$ & $12.31 \pm 6.59$ & $14.14 \pm 8.60$ & $0.49 \pm 0.05$ & $2.57 \pm 0.20$ & $19.05 \pm 2.38$ & 238 & 28 & 0.91 \\
\hline & C & $5 / 30 / 2008$ & $14.51 \pm 1.39$ & 1.16 & 0.10 & 13.01 & $1.48 \pm 0.62$ & $0.05 \pm 0.06$ & $2.83 \pm 2.64$ & $8.37 \pm 0.21$ & $14.82 \pm 5.36$ & $0.52 \pm 0.01$ & $2.69 \pm 0.11$ & $19.48 \pm 1.03$ & 258 & 36 & 0.87 \\
\hline & D & 06/08/2008 & $11.37 \pm 1.27$ & 1.00 & 0.10 & 12.03 & $0.09 \pm 0.13$ & 0.00 & 0.00 & $5.47 \pm 2.24$ & $1.30 \pm 1.84$ & $0.51 \pm 0.14$ & $2.33 \pm 0.50$ & $21.73 \pm 1.36$ & 202 & 24 & 0.80 \\
\hline \multirow[t]{5}{*}{$\begin{array}{l}\text { December } \\
2008\end{array}$} & A & $12 / 04 / 2008$ & $69.18 \pm 19.22$ & 1.22 & 0.05 & 28.15 & $2.14 \pm 1.06$ & $0.56 \pm 0.31$ & $25.71 \pm 5.52$ & $6.49 \pm 3.43$ & $24.83 \pm 1.86$ & $0.41 \pm 0.20$ & $2.57 \pm 1.37$ & $16.27 \pm 0.70$ & 260 & 21 & 0.75 \\
\hline & B & 12/03/2008 & $21.58 \pm 3.85$ & 1.96 & 0.13 & 18.09 & $5.01 \pm 0.80$ & $1.05 \pm 0.12$ & $21.05 \pm 0.99$ & $17.45 \pm 0.98$ & $22.20 \pm 1.87$ & $0.83 \pm 0.04$ & $5.48 \pm 0.59$ & $15.25 \pm 1.07$ & 344 & 32 & 0.83 \\
\hline & $\mathrm{N}$ & $12 / 08 / 2008$ & 13.58 & 1.36 & 0.10 & 16.28 & $1.47 \pm 0.21$ & $0.05 \pm 0.02$ & $3.53 \pm 0.74$ & $13.17 \pm 1.04$ & $10.03 \pm 1.41$ & $0.61 \pm 0.06$ & $3.06 \pm 0.11$ & $19.87 \pm 2.65$ & 622 & 37 & 0.64 \\
\hline & C & $12 / 04 / 2008$ & 17.11 & 1.49 & 0.10 & 18.01 & $0.98 \pm 0.20$ & 0.00 & 0.00 & $13.28 \pm 0.72$ & $6.85 \pm 1.00$ & $0.55 \pm 0.05$ & $3.05 \pm 0.27$ & $18.07 \pm 0.95$ & 246 & 25 & 0.78 \\
\hline & D & $12 / 08 / 2008$ & 15.57 & 1.16 & 0.08 & 16.08 & $0.18 \pm 0.03$ & 0.00 & 0.00 & $10.77 \pm 1.31$ & $1.66 \pm 0.28$ & $0.45 \pm 0.06$ & $2.53 \pm 0.13$ & $18.01 \pm 2.54$ & 210 & 28 & 0.78 \\
\hline \multirow[t]{5}{*}{$\begin{array}{l}\text { July } \\
2011\end{array}$} & A & 7/26/2011 & 26.08 & $1.80 \pm 0.14$ & 0.15 & 14.03 & $5.94 \pm 0.91$ & $0.59 \pm 0.21$ & $9.86 \pm 7.14$ & $7.14 \pm 0.07$ & $45.22 \pm 3.92$ & $1.13 \pm 0.02$ & $2.96 \pm 0.21$ & $38.44 \pm 2.25$ & 1522 & 57 & 0.61 \\
\hline & B & 7/21/2011 & 12.92 & $1.54 \pm 0.14$ & 0.14 & 12.98 & $1.04 \pm 0.54$ & $0.17 \pm 0.11$ & $15.85 \pm 6.52$ & $6.52 \pm 1.90$ & $13.24 \pm 2.62$ & $0.81 \pm 0.07$ & $2.71 \pm 0.20$ & $30.04 \pm 2.12$ & 1700 & 45 & 0.57 \\
\hline & $\mathrm{N}$ & 7/30/2011 & 11.07 & $1.25 \pm 0.05$ & 0.11 & 12.91 & $0.80 \pm 0.29$ & $0.06 \pm 0.02$ & $06.93 \pm 4.13$ & $4.13 \pm 0.52$ & $15.89 \pm 3.21$ & $0.66 \pm 0.05$ & $2.02 \pm 0.12$ & $32.58 \pm 0.97$ & 426 & 41 & 0.85 \\
\hline & c & 7/25/2011 & 10.32 & $1.21 \pm 0.10$ & 0.09 & 15.7 & $0.39 \pm 0.17$ & 0.00 & 0.00 & $3.25 \pm 0.21$ & $10.72 \pm 4.90$ & $0.65 \pm 0.00$ & $2.03 \pm 0.06$ & $32.14 \pm 1.12$ & 442 & 41 & 0.69 \\
\hline & D & 7/28/2011 & 9.88 & $1.08 \pm 0.03$ & 0.08 & 15.36 & $0.43 \pm 0.02$ & 0.00 & 0.00 & $3.78 \pm 0.10$ & $10.27 \pm 0.67$ & $0.62 \pm 0.07$ & $1.88 \pm 0.09$ & $32.62 \pm 2.18$ & 284 & 39 & 0.83 \\
\hline
\end{tabular}




\section{Figure Captions}

Figure 1: Delimitations of the different Rhône River basins (A) (from Antonelli et al., 2008) and locations of the 5 sampled stations within the Rhône River mouth area (B) (Gulf of Lions, NorthWestern Mediterranean Sea).

Figure 2: Temporal changes in Rhône River mean daily water flow (A) and suspended particulate matter (SPM) (B) between 2007 and 2011. Vertical dashed lines indicate the last floods (> 3000 $\mathrm{m}^{3} \cdot \mathrm{s}^{-1}$ ) recorded before the 4 sampling cruises (vertical grey lines). The first 3 floods were characterized by Zebracki et al. (2015) and the last one based on SPM.

Figure 3: Spatiotemporal changes in surface sediment characteristics: $D_{0.5}$ : median grain size (A), OC: organic carbon (B), EHAA: enzymatically hydrolysable amino acids (C), Chl-a: chlorophyll-a (D), EHAA/THAA: ratio between enzymatically and total hydrolysable amino acids (E) and Chla/(Chl-a+Phaeo-a): ratio between chlorophyll-a and the sum of chlorophyll-a and phaeophytin-a (F). Vertical bars are standard deviations.

Figure 4: Non-metric Multidimensional Scaling (nMDS) (A) and hierarchical clustering (Euclidean distance and average group method) (B) of normalized surface sediment characteristics. Grey lines indicate groups of samples (combinations of stations and dates), which do not show significant differences in their characteristics (SIMPROF test, $p>0.05$ ). Letters refer to stations and symbols to dates.

Figure 5: Spatiotemporal changes in benthic macrofauna main characteristics: abundance $(A)$, species richness (B) and Pielou's evenness (C).

Figure 6: Non-metric Multidimensional Scaling (nMDS) (A) and hierarchical clustering (Bray-Curtis similarity and average group method) (B) of macrofauna abundance data (square-root transformed). Grey lines indicate groups of samples (combinations of stations and dates), which do not show significant difference in their macrofauna composition (SIMPROF test, $p>0.05$ ). Letters refer to stations and symbols to cruises. 
Figure 7: Examples of sediment profile images collected at 3 stations along the main inshore/offshore gradient (stations A, B and C) during 3 different cruises (April 2007, May 2008 and July 2011). The aRPD (apparent Redox Potential Discontinuity) is drawn in blue and the flood layer in light blue. Biogenic structures are also highlighted: OV: oxic voids (red), T: tubes (yellow), B: burrow (white), l: infauna (green). 

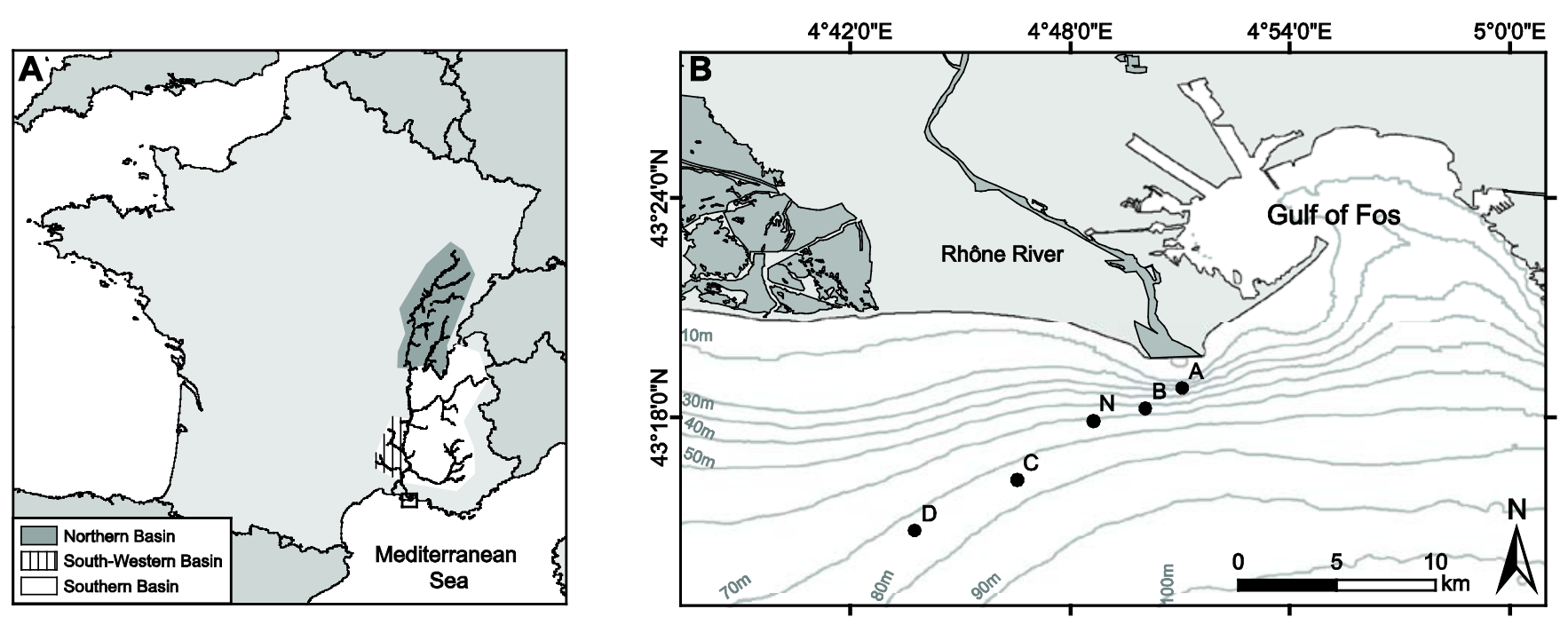

Figure 1 


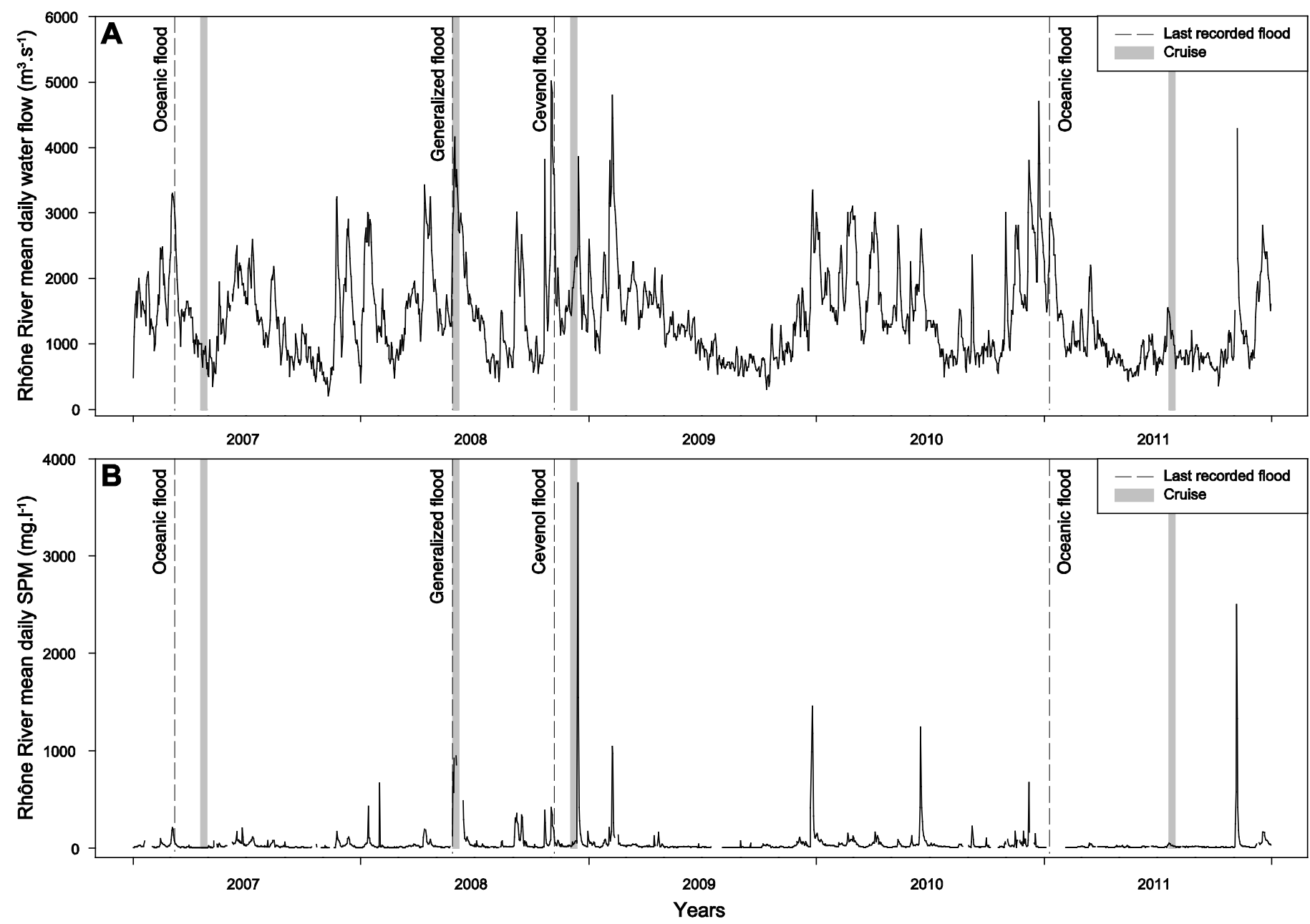

Figure 2 

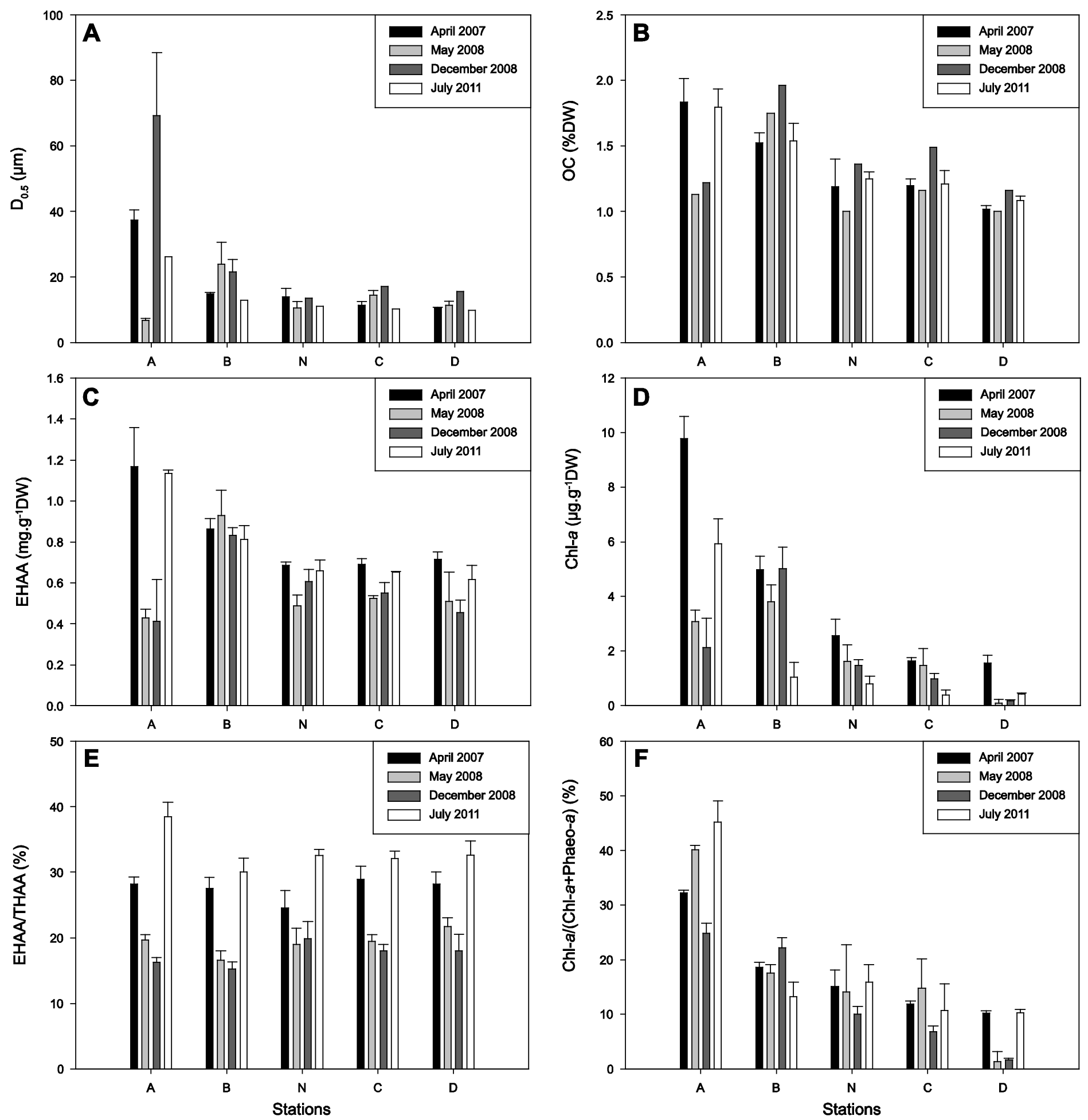

Figure 3 


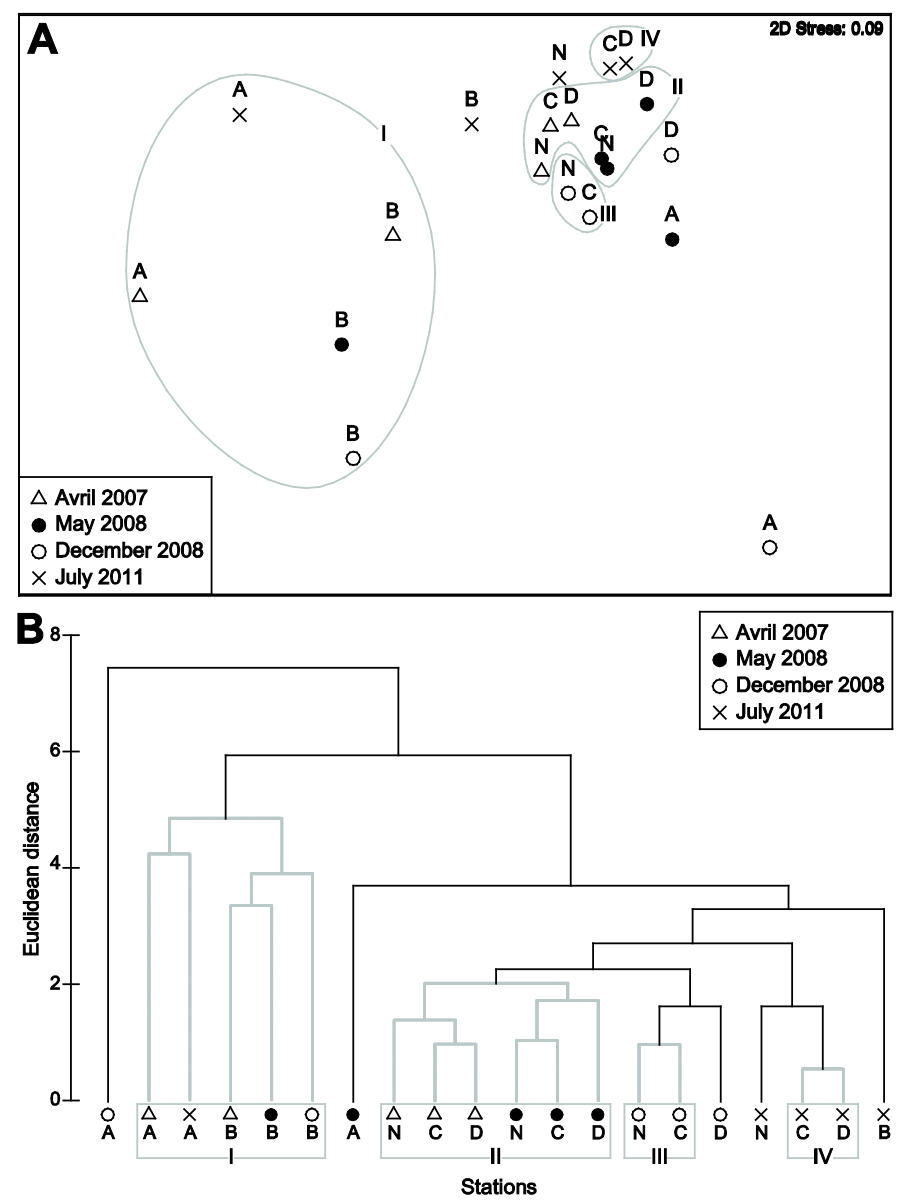

Figure 4 

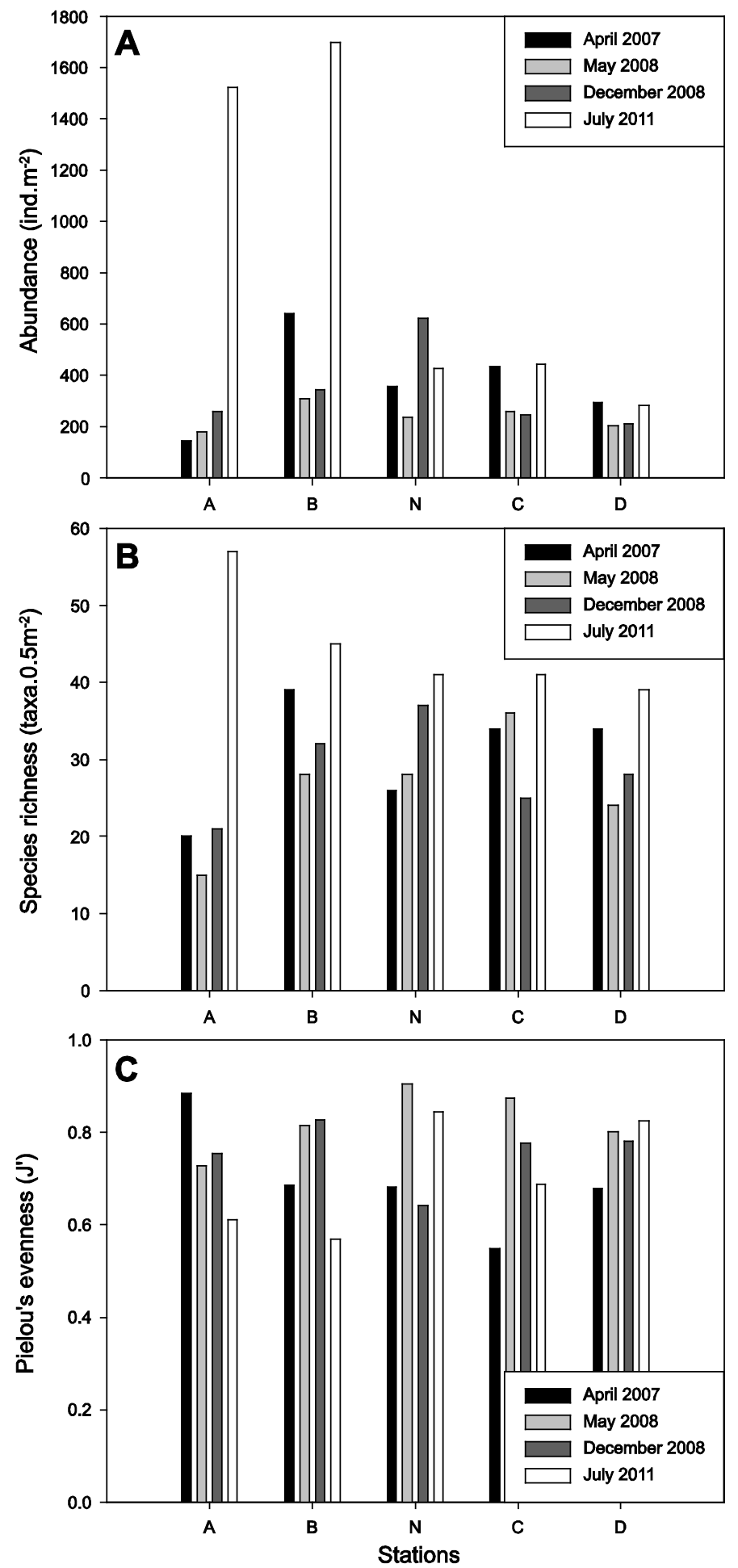

Figure 5 


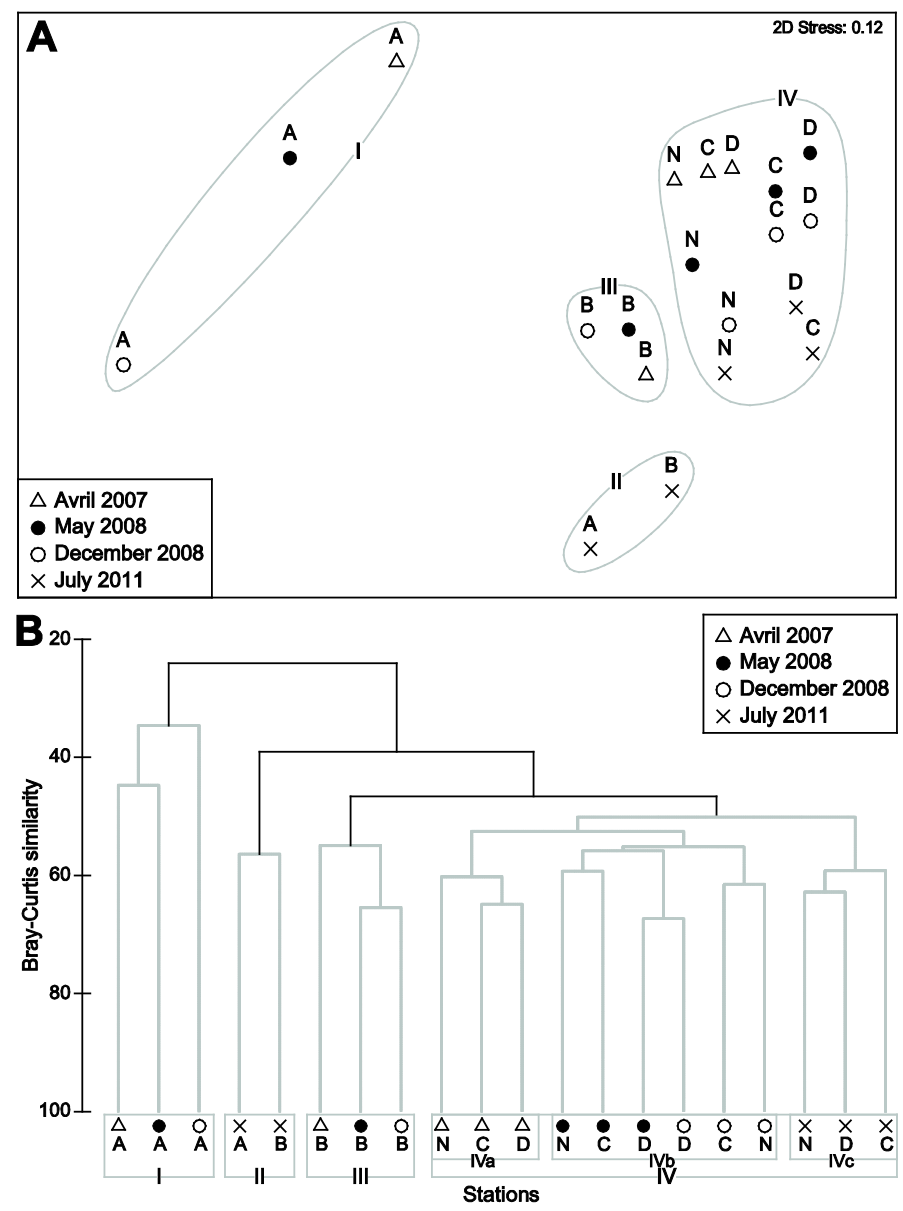

Figure 6 


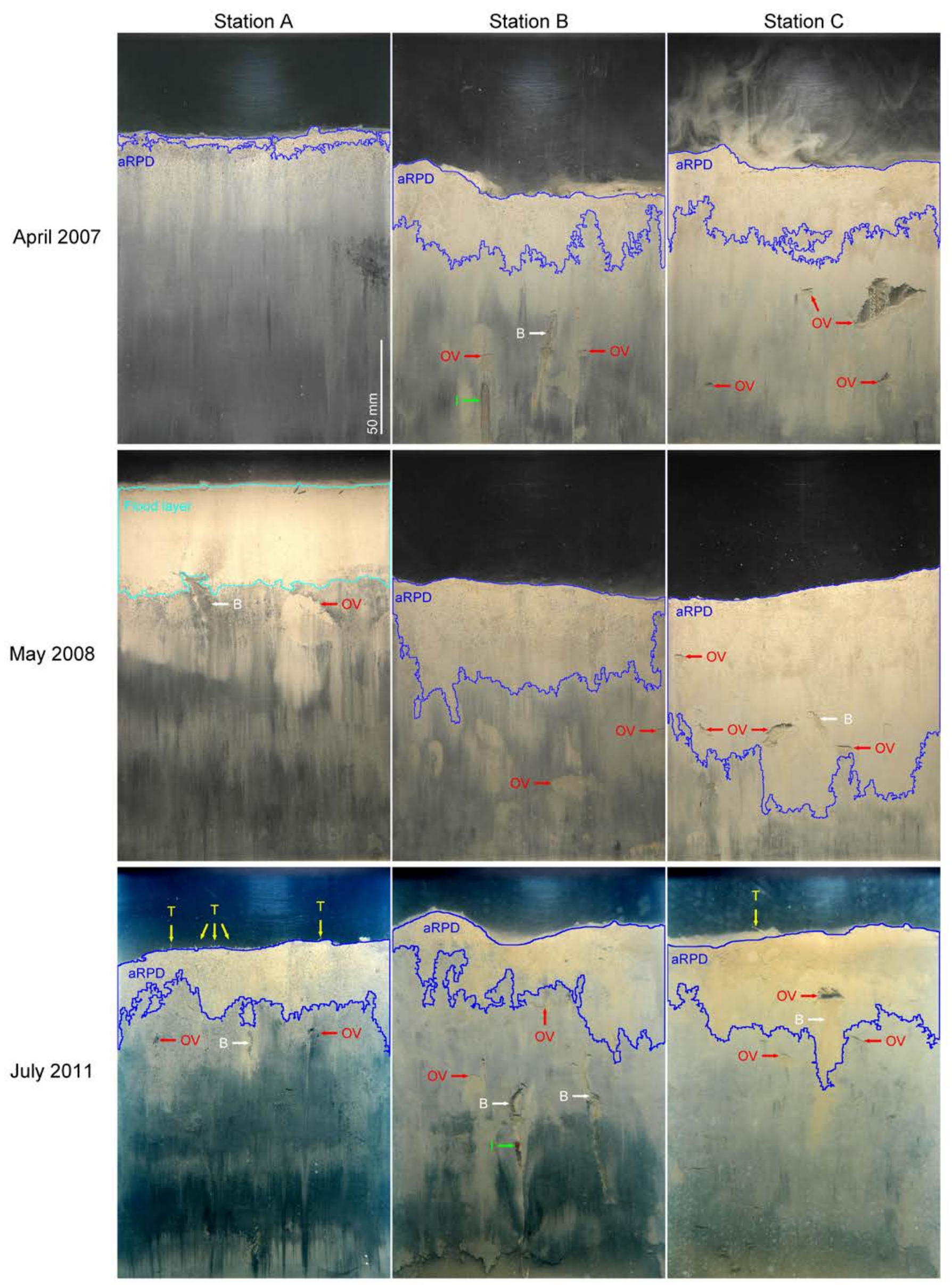

Figure 7 